\title{
Schneiderian Papillomas and Nonsalivary Glandular Neoplasms of the Head and Neck
}

Leon Barnes, M.D.

\author{
University of Pittsburgh Medical Center, Presbyterian Hospital, Pittsburgh, Pennsylvania
}

Schneiderian papillomas and nonsalivary glandular neoplasms of the head and neck continue to be a source of confusion for both the clinician and pathologist. An update on these lesions is provided.

KEY WORDS: Aggressive papillary middle ear tumor, Cylindrical cell papilloma, Fungiform papilloma, Intestinal-type adenocarcinoma, Inverted papilloma, Low-grade papillary adenocarcinoma of middle ear, Oncocytic Schneiderian papilloma, Papillary adenocarcinoma of the nasopharynx, Respiratory epithelial adenomatoid hamartoma, Schneiderian papilloma.

Mod Pathol 2002;15(3):279-297

Schneiderian papillomas and nonsalivary glandular neoplasms of the head and neck are uncommon and, by light microscopy, often exhibit overlapping papillary and/or glandular features. As a result, they may be confused or even mistaken for metastatic tumors. A review of selected lesions follows.

\section{SCHNEIDERIAN PAPILLOMAS}

The ectodermally derived ciliated respiratory mucosa that lines the sinonasal tract, so-called Schneiderian membrane, gives rise to three morphologically distinct papillomas. These are referred to individually as the fungiform, inverted, and oncocytic papillomas or, collectively, as Schneiderian papillomas.

Ever since their first recognition by Ward in 1854 (1), papillomas of the sinonasal tract have been the center of controversy over their nomenclature, etiology, pathology, and biological behavior. Over the years, more than 50 different terms have been ap-

Copyright (C) 2002 by The United States and Canadian Academy of Pathology, Inc.

VOL. 15, NO. 3, P. 279, 2002 Printed in the U.S.A.

Date of acceptance: September 27, 2001.

This manuscript was presented as part of the United States and Canadian Academy of Pathology Long Course on 'Tumors of the Head and Neck, March 7, 2001, Atlanta, Georgia.

Address reprint requests to: Leon Barnes, M.D., Department of Pathology, UPMC Presbyterian, 200 Lothrop Street, Pittsburgh, PA 15213; e-mail: barnesel@msx.upmc.edu; fax: 412-647-6251. plied to these lesions. It was Hyams who, in 1971 (2), largely brought some order to this chaos when he reported the clinicopathological features of 315 Schneiderian papillomas on file at the Armed Forces Institute of Pathology and proposed that they be subclassified into three types, as basically noted above.

There are some, however, who still consider these three lesions to be a single entity and group them together under such generic terms as papilloma, papillomatosis, or Schneiderian papilloma $(3,4)$. Others are firmly convinced that there are sufficient clinical, pathological, and potential etiological differences among these papillomas to warrant their separation (5).

As a group, Schneiderian papillomas are uncommon, representing only $0.4-4.7 \%$ of all sinonasal tumors (6). Nasal polyps for instance, are stated to be 25-60 times more common than papillomas (3, 7).

Although the etiology is unsettled, a viral origin, at least for the fungiform and IPs, has been proposed. An association with allergy, inflammation, smoking, environmental noxious agents, or occupation is not convincing $(2,8)$.

Although Fu et al. (9) have reported a series of nine patients with Schneiderian papillomas who also had a history of genital and/or anogenital papillomas, it is generally concluded that patients with sinonasal papillomas do not exhibit an increased tendency for developing papillomas in other sites.

The frequency of the various types of Schneiderian papillomas varies according to institution. In a collective review of 728 cases, $32 \%$ were of the fungiform type (range, 6-50\%); 62\%, inverted (range, $47-78 \%$ ); and $6 \%$, oncocytic (range, $2-26 \%)(2,5$, 10-12; Table 1).

\section{Fungiform Papilloma (Exophytic Papilloma, Septal Papilloma, Squamous Papilloma)}

\section{Clinical Features}

Fungiform papillomas (FP) are 2 to 10 times more common in men and occur primarily in individuals 


\begin{tabular}{lccc}
\hline \multicolumn{1}{c}{ Reference (No.) } & Total & Fungiform & Inverted \\
\hline Hyams (2) & 315 & 156 & 149 \\
Michaels and Young (5) & 191 & 36 & 139 \\
Buchwald et al. (10) & 82 & 19 & 58 \\
Sarkar et al. (11) & 35 & 2 & 24 \\
Weiner et al. (12) & 105 & 21 & 52 \\
Total & $728(100 \%)$ & $234(32 \%)$ & $452(62 \%)$ \\
\hline
\end{tabular}

between 20 and 50 years of age (range, 21-87 years) $(2,13)$. They characteristically arise on the nasal septum, usually the anterior portion; only $4-21 \%$ originate in or involve the lateral nasal wall $(2,14$, 15). Involvement of the paranasal sinuses is distinctly unusual, if indeed it occurs at all. There is no significant lateralization to either side of the nose. Generally solitary and discrete, they may be multifocal, but bilaterality is rare (3.6\%) (11). Epistaxis, unilateral nasal obstruction, or the presence of an asymptomatic mass are the typical presenting symptoms.

On physical examination, FPs appear as exophytic, papillary, or warty; gray, pink, or tan; nontranslucent growths attached to the nasal septum by a relatively broad base.

\section{Etiology}

There is increasing evidence to suggest that FPs may be etiologically related to the human papilloma virus, especially types 6 and 11, rarely Types 16 and 57b. In a collective review of 79 FPs evaluated for the presence of human papillomavirus (HPV) by in situ hybridization and/or the polymerase chain reaction, 45 (57\%) were HPV positive $(9-11,16-21)$.

\section{Radiography}

Radiographic evaluation of FP is generally not indicated. At most, the lesion will appear as a soft tissue density along the nasal septum with little, if any, evidence of septal erosion.

\section{Pathology}

Most FPs range from a few millimeters up to about $2 \mathrm{~cm}$. Microscopically, they are composed of papillary fronds with delicate fibrovascular cores covered by epithelium, $5-20$ cells thick, that varies from squamous to transitional (intermediate) to ciliated, pseudostratified columnar (respiratory; Fig. 1). Scattered mucin-containing cells, representing residual goblet cells, are common. Surface keratinization is absent or scant, unless the patient is a 'nose picker' and irritates the lesion or if the papilloma is unusually large and hangs into the nasal vestibule, where it is more exposed to the drying effect of ambient air. In these instances, surface

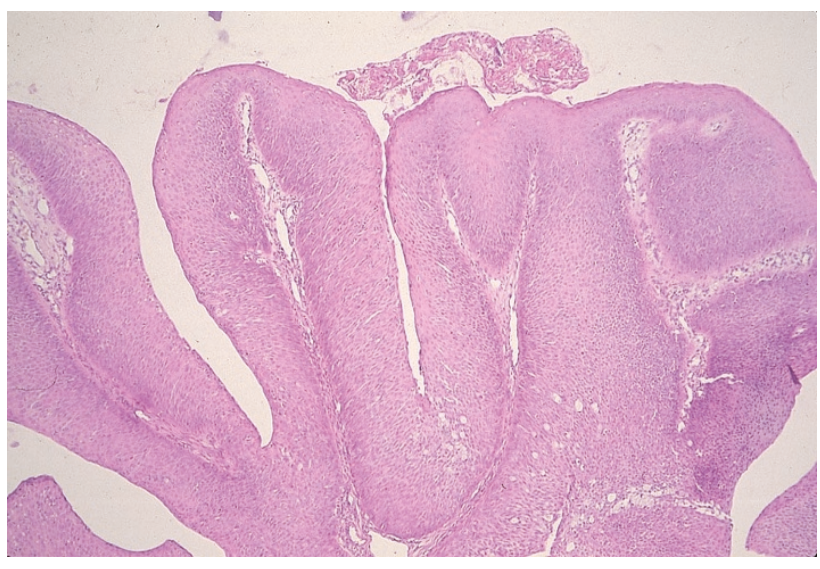

FIGURE 1. Fungiform papilloma. Note the exophytic growth, absence of surface keratinization, and presence of a few scattered intraepithelial mucous cells (clear cells).

keratin may be apparent. Mitoses are rare and never atypical, and unless infected or irritated, the stroma contains few inflammatory cells.

Although Norris (13) and Buchwald et al. (22) have each described a FP associated with an invasive squamous cell carcinoma, this is an exceptional occurrence. Most authorities agree that FPs, in contrast with other Schneiderian papillomas, are not associated with an increased incidence of carcinoma.

\section{Differential Diagnosis}

FPs must be distinguished from the much more common, keratinizing cutaneous papillomas (e.g., verruca vulgaris) occurring in the nasal vestibule. The lack of extensive surface keratinization and the presence of mucous cells (accentuated by mucin stains) and ciliated and/or 'transitional' epithelium serve to distinguish FPs from cutaneous papillomas. In addition, the presence of minor salivary glands and septal cartilage further indicate that the lesion is of mucosal rather than cutaneous origin.

\section{Treatment and Prognosis}

Complete surgical excision is the treatment of choice. Because the majority of recurrences tend to occur in the site of previous removal, inadequate excision rather than multiplicity of lesions probably 
accounts for the $22-50 \%$ incidence of local recurrence that has been reported in the past $(2,7,13)$.

\section{Inverted Papilloma}

\section{Clinical Features}

Inverted papillomas (IP) are two to five times more common in males and are found primarily in the $40-70$-year age group $(2,3,8,14,15,23-30)$. The 6 -year-old boy included in the series of Eavey (31) is one of the youngest patients yet described with this papilloma.

These papillomas characteristically arise from the lateral nasal wall in the region of the middle turbinate or ethmoid recesses and often extend secondarily into the sinuses, especially the maxillary and ethmoid and, to a lesser extent, the sphenoid and frontal. Isolated lesions of the paranasal sinuses without nasal involvement, however, do occur (32). Only about $8 \%$ of IPs arise from the nasal septum (33). Their rarity on the nasal septum may, in part, be related to the fact that there is little soft tissue in the septum for the lesion to invert into before it meets the resistance of the underlying septal cartilage, which in turn would force the lesion to grow exophytically.

Although reported to be bilateral in $0-10 \%$ of cases, such an occurrence should always arouse the suspicion of septal erosion and perforation from unilateral disease $(2,3,15,24,29)$.

Exceptionally, IPs may arise in sites other than the sinonasal tract. They have been recorded in middle ear-mastoid (34), pharynx $(35,36)$, nasopharynx (37), lacrimal sac (38), and possibly in the wall of a branchial cleft cyst (39). It has been suggested that ectopic migration of the Schneiderian membrane during embryogenesis could account for these aberrant papillomas in sites contiguous with the sinonasal tract (2). Whether all of these ectopic cases are bona fide IPs is uncertain.

Unilateral nasal obstruction is the most common presenting symptom. Other manifestations include nasal drainage, epistaxis (10-20\% of cases), anosmia, headaches (especially frontal), epiphora, proptosis, and diplopia. Pain, on the other hand, is an uncommon initial complaint, occurring in only about $10 \%$ of all cases. When present, it should always arouse suspicion of secondary infection or even a malignant change (24).

On physical examination, IPs present as pink, tan, or gray; nontranslucent; soft to moderately firm polypoid growths with a convoluted or wrinkled surface (Fig. 2).

\section{Etiology}

Although IPs have long been suspected of being of viral origin, viral inclusions have never been un-

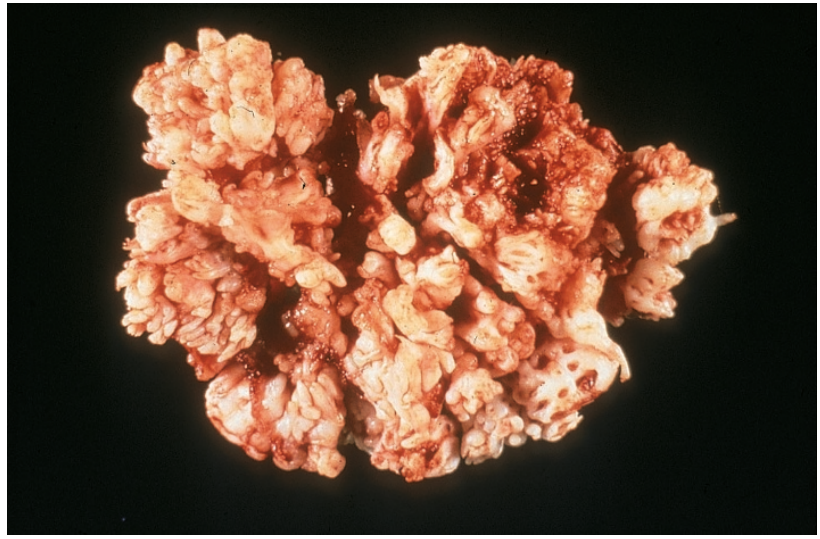

FIGURE 2. Inverted papilloma removed intact via a lateral rhinotomy and medial maxillectomy. Papillary structures are opaque and will not transilluminate.

equivocally demonstrated by either light or electron microscopy. In addition, they are almost invariably negative when stained for HPV by the immunoperoxidase technique. Recently, however, some investigators have demonstrated HPV genomes in IPs by in situ hybridization or the polymerase chain reaction, particularly HPV 6 and 11, sometimes HPV 16 and 18, and exceptionally, HPV 57. The frequency of finding the virus by these specialized techniques is highly variable, ranging anywhere from 0 to $100 \%$ $(9-11,16-21,40-50)$. In a collective review of 341 IPs evaluated for the presence of HPV by a variety of sophisticated molecular techniques, 131 (38\%) have been positive.

Macdonald et al. (51) have found evidence of the Epstein-Barr virus (EBV) DNA in 13 of 20 (65\%) IPs by polymerase chain reaction and have raised the possibility that this virus might be involved in its pathogenesis. Gaffey et al. (21),on the other hand, in an in situ hybridization study of 19 IPs (one of which was associated with squamous cell carcinoma), found no evidence of EBV. Obviously, more studies are needed to resolve these conflicting data and the relationship, if any, between IP and EBV.

\section{Radiography}

The radiographic findings vary with the extent of the disease (52). Early on, there may be only a soft tissue density within the nasal cavity and/or paranasal sinuses. Later, with more extensive disease, unilateral opacification and thickening of one or more of the sinuses is common, as are expansion and displacement of adjacent structures. Pressure erosion of bone may also be apparent and must be distinguished from osseous invasion associated with malignancy. Extensive bone destruction should always raise the possibility of a carcinoma arising in and/or associated with an IP. 


\section{Pathology}

Microscopically, IPs are composed of hyperplastic ribbons of basement membrane-enclosed epithelium that grow endophytically into the underlying stroma (Fig. 3). The epithelium is multilayered, usually 5-30 cells thick, and formed of squamous or ciliated, columnar (respiratory epithelial) cells admixed with goblet cells (Fig. 4). Nonkeratinizing squamous epithelium tends to predominate, but occasionally a case may be composed almost entirely of respiratory epithelium. Gradations between these two extremes are not uncommon, resulting in a transitional epithelium reminiscent of that seen in the urinary tract. All of these epithelial types may be present in the same lesion, and their proportions may vary widely in different lesions or even in different areas of the same papilloma. Mitoses are not numerous and, if present at all, are seen primarily in the basal and parabasal epithelium.

Ten to $20 \%$ of IPs may show focal surface keratinization and $5-20 \%$ varying degrees of dysplasia (2, $8,23,49,53,54)$. These are not necessarily signs of malignancy, but they should alert the pathologist of the need for thorough evaluation of the papilloma.

The stroma ranges from dense and fibrous to loose and myxoid, with or without an inflammatory component. The inflammatory cells, especially neutrophils, often transmigrate through the epithelium. Eosinophils and basement membrane thickening are not typically seen (Fig. 4). Minor salivary glands are also sparse to absent because of the fact that the abnormal epithelium uses the salivary ducts and glands as scaffolds to extend into the stroma, thereby obscuring their normal appearance.

As IPs enlarge, they may obstruct the drainage of nearby sinuses. As a result, it is not uncommon to also find ordinary nasal polyps in IP specimens.

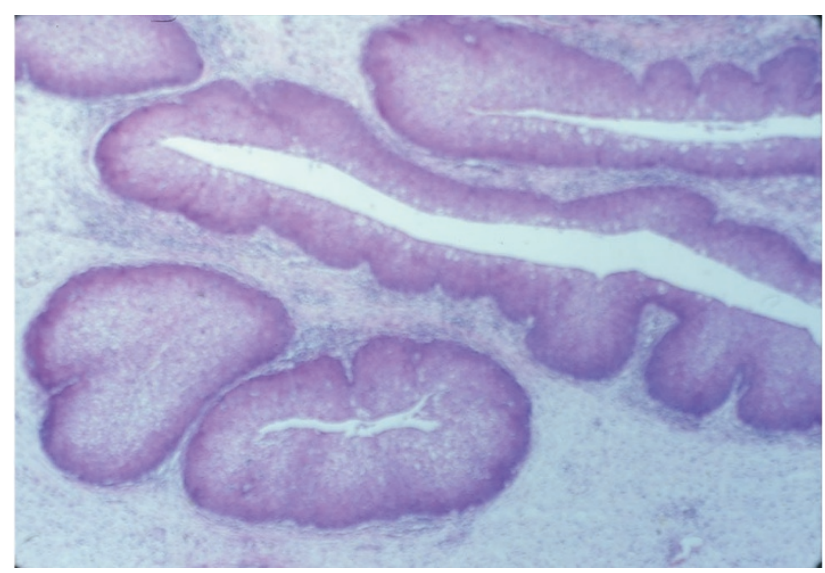

FIGURE 3. Inverted papilloma, low magnification. Note the endophytic growth and that the epithelial islands are well demarcated from the stroma.

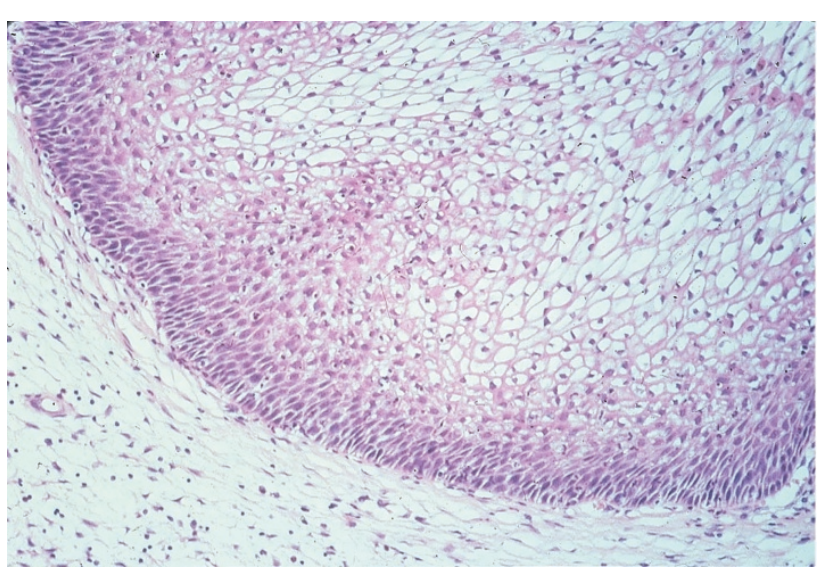

FIGURE 4. Inverted papilloma composed of 'glycogenated' squamous cells. Basement membrane is thin and delicate.

They can usually be identified grossly by their more myxoid appearance and the fact that they will transilluminate, whereas IP will not.

Rarely, an IP will exhibit focal surface changes reminiscent of a verruca vulgaris; that is, it will show focal papillary squamous epithelial hyperplasia with marked keratosis and/or parakeratosis, with or without a prominent granular cell layer, and often contain numerous vacuolated cells suggestive of koilocytes. Although this might be a viral effect, immunohistochemical stains for HPV are invariably negative. When this change is observed, the diagnosis of 'IP with focal verrucoid (verrucous) hyperplasia' might be appropriate. This change has no clinical significance other than it might be mistaken for a verrucous carcinoma (see later section on differential diagnosis).

\section{Carcinoma and IP}

IPs are occasionally complicated by carcinomas, especially squamous cell carcinoma and, to a much lesser extent, verrucous (55), mucoepidermoid (3), spindle and clear cell carcinomas (7), as well as adenocarcinoma (52), The incidence of malignant change in individual series of IPs has ranged anywhere from 2 to $27 \%(2-4,8,10,14,25-30,45,48,49$, $53,54,56-60)$. In a collective review of 1390 IPs reported in the literature, $150(11 \%)$ were associated with carcinoma.

Patients with IPs that are associated with carcinomas fall into three groups: (1) those who have primarily an IP with only a small focus of carcinoma, (2) those who have primarily a carcinoma with only a small focus of IP, and (3) those who have an IP and then years later develop a carcinoma in the area in which the papilloma arose.

Of all carcinomas associated with IPs, approximately $61 \%$ are synchronous and 39\% metachronous. For metachronous carcinomas, Lesperance and Esclamado (60) observed the mean interval 
between the onset of the IP and the development of carcinoma to be 63 months (range, 6 mo to 13 years).

Carcinomas complicating IPs vary from well to poorly differentiated and exhibit a broad range of behavior. Some are in situ and of little consequence, whereas others are locally aggressive or may even metastasize.

The carcinomas may actually arise within the papilloma (carcinoma ex IP), as evidenced by a gradation of histologic changes ranging from dysplasia to carcinoma in situ to frankly invasive carcinoma; whereas in others, the carcinoma is merely associated with a histologically bland IP. Once a carcinoma is recognized, the pathologist should not only indicate the histologic type, the degree of invasion and differentiation, and the adequacy of resection margins (if possible) but also quantitate its volume (e.g., the specimen consists of $30 \%$ IP and $70 \%$ poorly differentiated squamous cell carcinoma).

There is no correlation between the number of local recurrences of an IP and the subsequent development of carcinoma (24). There is some evidence, however, to suggest that HPV 16 and 18 may be more carcinogenic than HPV 6 and $11(45,46$, 49). In the studies of Klemi et al. (45) and Siivonen and Virolainen (46), 3 of 8 (38\%) IPs that contained HPV 16 also had carcinoma. Klemi et al. (45) also studied 19 IPs by flow cytometry. Six of 19 (32\%) were aneuploid, and of the 6 that were aneuploid, 2 (33\%) were associated with carcinomas. Only 1 of the 13 (8\%) diploid IPs was associated with carcinoma. They indicated that if the papillomas were both HPV 16 positive and aneuploid, the incidence of malignant transformation was even higher.

Preliminary data suggest that alterations in p53, manifested by an increased protein expression or genetic mutation, may be used to predict which lesions are at risk for malignant changes (61-63). CD44s may likewise prove useful. According to Ingle et al. (64), CD44s is diffusely expressed in typical IPs, whereas in IP with an invasive squamous cell carcinoma, the expression of CD44s in the malignant component is reduced or absent.

\section{Differential Diagnosis}

The differential diagnosis includes nasal polyps with squamous metaplasia, respiratory epithelial adenomatoid hyperplasia, inverted ductal papilloma (IDP) of minor salivary gland origin, and invasive carcinoma.

In nasal polyps with squamous metaplasia, one will usually see thickening and hyalinization of the basement membrane, prominent minor salivary glands, and, often, a large number of inflammatory cells, especially eosinophils. These features are absent in IP. In addition, the epithelium lining the minor salivary glands in nasal polyps is not multilayered, contains more mucous cells, and does not show the characteristic epithelial transmigration of neutrophils.

Features that are useful in distinguishing respiratory epithelial adenomatoid hamartoma from IP are covered in the section below titled "Respiratory Epithelial Adenomatoid Hamartoma." Although IDP and IP share similar names, they should not be confused (65). The former is innocuous compared with the potentially locally aggressive behavior of the latter. In contrast to IP, which arises from the surface epithelium and grows endophytically, IDP arises from the excretory duct of minor salivary glands; hence it will grow intraluminally and be confined by the duct.

Invasive carcinoma can be distinguished from the ordinary IP by the presence of the following features in the former lesion and their absence in the latter: cellular pleomorphism, atypical mitoses, keratin pearls, loss of basement membranes, and unequivocal invasion associated with an inflammatory-desmoplastic stromal response.

\section{Treatment and Prognosis}

Inverted papillomas are thought to enlarge by squamous metaplasia of the adjacent mucosa. Though histologically benign, they have an unlimited growth potential and, if neglected, can cause considerable morbidity or even death by extending into contiguous structures (66). Attempts to remove these lesions intranasally by snare and avulsion have resulted in 'recurrence" (or persistence) rates of 0 to $74 \%$ (average, $60 \%$ ) (30).

The preferred treatment for most lesions is a lateral rhinotomy and medial maxillectomy with meticulous removal of all mucosa in the ipsilateral paranasal sinuses $(25,55)$. With this approach, the incidence of recurrence averages $16 \%$ (range, 0 to $30 \%)$ (30). In selected, very small tumors, one may, however, be able to effectively remove the lesion by a less aggressive approach using endoscopic sinonasal surgery (67).

Although surgery is, and should remain, the primary treatment modality for IP, Mendenhall et al. (68) have suggested that radiation therapy may have merit in a small subset of patients with advanced or incompletely resected tumors. Radiation therapy should also be considered as an adjunct in patients who have carcinomas arising in IPs.

Recurrences typically appear within 2-3 years of therapy but, in some instances, are delayed for many years. Attempts to correlate histologic features with risk of recurrence have resulted in conflicting data. Some maintain that the presence of epithelial atypia and mucin cells render the patient at increased risk (3), whereas others comment on 
the lack of association with any microscopic feature (2, 30, 53, 69). Even those with prominent mitotic activity and dysplasia do not invariably show an increased incidence of recurrence or malignancy. Nevertheless, dysplasia, especially if moderate to severe, demands thorough microscopic evaluation of all resected tissue so as to avoid overlooking small foci of cancer.

Whether the demonstration of HPV in IP is associated with a greater risk of local recurrences is also open to debate. Beck et al. (49) noted that patients whose IP contained HPV often developed relapses, whereas Furuta et al. (48) found no relationship between HPV infection and local recurrence.

\section{Oncocytic Schneiderian Papilloma (Cylindrical Cell Papilloma, Columnar Cell Papilloma)}

\section{Clinical Features}

Oncocytic Schneiderian papilloma (OSP) is the rarest of the three morphologic variants of Schneiderian papillomas $(2,5,10,70-72)$. It shows many features in common with the IP. In fact, some regard it as only a variant of the IP. Microscopically, however, the two lesions are distinct.

OSP is equally distributed between the sexes, and the majority of the patients are $>50$ years of age at the time of diagnosis. The youngest patient reported thus far in the literature has been a 33-yearold woman (73).

OSP occurs exclusively on the lateral nasal wall or in the sinuses, usually the maxillary or ethmoid, and presents as a fleshy pink, tan, red-brown, or gray papillary or polypoid growth. Unilateral nasal obstruction and intermittent epistaxis are the most common symptoms.

\section{Etiology}

At least 22 cases of OSPs have been examined by in situ hybridization and/or polymerase chain reaction for the presence of HPV, and all have been negative $(10,11,16,17,21)$. This is in contrast to the fungiform and IPs in which HPV has been found in many instances. Although this may be a sampling problem, it does suggest that the OSP is not etiologically linked to this virus.

\section{Radiography}

The radiographic features are identical to those of the IP described above.

\section{Pathology}

Microscopically, OSP exhibits both exophytic and endophytic patterns of growth. The epithelium is multilayered, 2-8 cells thick, and is composed of tall columnar cells with swollen, finely granular cytoplasm reminiscent of oncocytes (Fig. 5). Barnes and Bedetti (70) have shown that the cells not only resemble oncocytes but also possess a high content of cytochrome $c$ oxidase and ultrastructurally are distended with mitochondria, thus clearly establishing their oncocytic character. The nuclei are either small dark and uniform or slightly vesicular with barely discernible nucleoli. Cilia in varying stages of regression may be observed in a few of the outermost cells.

The epithelium characteristically contains numerous small cysts filled with mucin or neutrophils (microabscesses; Fig. 5). The stroma varies from edematous to fibrous and may contain modest numbers of lymphocytes, plasma cells, and neutrophils, but few eosinophils. Minor salivary glands are sparse to absent.

\section{Carcinoma and OSP}

Approximately $4-17 \%$ of all OSPs may harbor a carcinoma $(2,70,74,75)$. Most of these are squamous, but mucoepidermoid, 'transitional,' and sinonasal undifferentiated carcinomas have also been described $(74,75)$.

As in IP, the carcinoma complicating OSP may actually arise within the papilloma, as evidenced by a gradation of histologic changes ranging from dysplasia to in situ to invasive carcinoma, or it may merely be associated with the OSP. Prognosis depends on the histologic type, degree of invasion, and the extent of tumor. In some instances, the carcinoma is in situ and of little consequence to the patient, whereas others are locally aggressive and may even metastasize.

\section{Differential Diagnosis}

The intraepithelial mucin-filled cysts, because of their spheroidal nature and mucicarminophilia, are

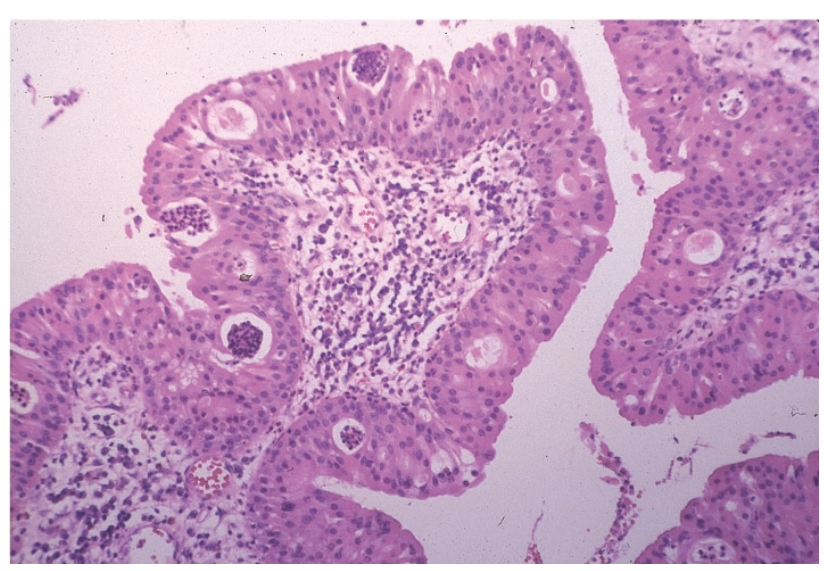

FIGURE 5. Oncocytic Schneiderian papilloma. Observe the multilayered oncocytic epithelium and intraepithelial mucin-filled cysts and microabscesses. 
often mistaken for rhinosporidiosis. In rhinosporidiosis, however, the organisms are not limited to the epithelium but also involve the stroma and, moreover, never induce a diffuse oncocytic change in the epithelium. The OSP is also occasionally mistaken for a low-grade papillary adenocarcinoma. The presence of intact basement membranes, the lack of nuclear pleomorphism, mitotic activity, perineural invasion, and the absence of extensive bone destruction on radiographs are features that point to the benignity of the tumor. Furthermore, the stratified oncocytic epithelium of an OSP is in distinct contrast to the single-layered, nononcocytic epithelium seen in a low-grade adenocarcinoma.

\section{Treatment and Prognosis}

The clinical behavior parallels that of the IP. Effective treatment consists of a lateral rhinotomy and medial maxillectomy. If inadequately excised, at least $25-35 \%$ will recur, usually within 5 years of treatment. Smaller tumors may be treated endoscopically.

\section{RESPIRATORY EPITHELIAL ADENOMATOID HAMARTOMA}

\section{Terminology}

Hamartomas (from the Greek, hamartia, meaning fault or defect) are benign, nonneoplastic overgrowths of tissue(s) indigenous to the area of their occurrence (76). They may be composed entirely of epithelial or mesenchymal elements or of both and should be distinguished from teratomas and dermoids (77-84).

Hamartomas of the sinonasal tract are uncommon and most often of the epithelial type. In 1995, Wenig and Heffner (85) described 31 cases of a unique benign glandular proliferation of respiratory epithelial cells of the nasal cavity, paranasal sinuses, and nasopharynx and designated the lesions as 'respiratory epithelial adenomatoid hamartomas (REAH).' They postulated that they arose from the surface epithelium in the setting of inflammatory polyps and were in all likelihood etiologically related to the inflammatory process. Their importance lies in the fact that they may be confused with more aggressive lesions, particularly the IP and sinonasal adenocarcinoma.

\section{Clinical Features}

Of the 31 REAHs described by Wenig and Heffner, 27 occurred in men and 4 in women who ranged in age from 27 to 81 years (median, 58 years). Most were unilateral and arose from the nasal cavity ( 22 cases, $71 \%$ ), particularly the posterior nasal septum and, to a lesser extent, along the lateral nasal wall, middle meatus, and inferior turbinate. A few, how- ever, were bilateral. The remaining cases occurred in the nasopharynx and paranasal sinuses.

Nasal stuffiness, obstruction, epistaxis, and chronic rhinosinusitis were the most common manifestations.

\section{Pathology}

REAHs are typically polypoid or exophytic, rubbery, tan-white to red-brown, and range up to 4.9 $\mathrm{cm}$. in greatest dimension. Histologically, they are composed of small to medium sized, round to oval glands lined by ciliated respiratory epithelium, often with numerous, admixed mucin-secreting (goblet) cells (Fig. 6). The glands arise from invagination of the surface epithelium into the lamina propria and, consequently, often maintain direct continuity with the surface. The glands are widely spaced and characteristically surrounded by thick, eosinophilic basement membranes (Fig 7). The stroma is well vascularized, edematous, or fibrous and contains scattered chronic inflammatory cells.

Mucoserous (minor salivary) glands are also occasionally seen in a lobular configuration. Whether they are part of the hamartoma or just a reactive hyperplastic response to the inflammation is uncertain, although the latter is favored (85). A few may also contain chondro-osseous foci (81).

Interestingly, 2 of the 31 patients with REAHs described by Wenig and Heffner (10) had additional simultaneous lesions; one had a combined ipsilateral REAH and IP and the other a solitary fibrous tumor on the side contralateral to the REAH.

\section{Differential Diagnosis}

REAHs are most often confused with ordinary nasal polyps, IPs, and adenocarcinomas. The presence of excess glands lined by respiratory epithelium readily distinguishes this lesion from a nasal polyp. In contrast to REAH, which occurs primarily

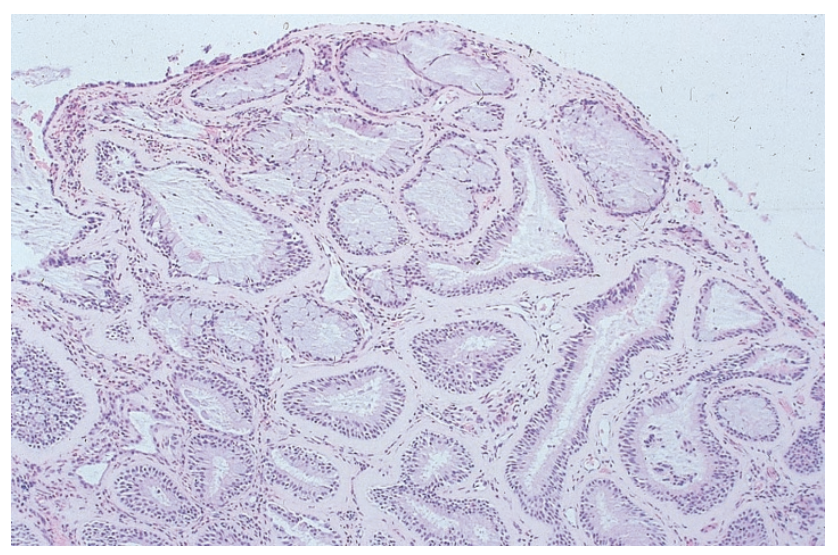

FIGURE 6. Respiratory epithelial adenomatoid hamartoma frequently mistaken for an inverted papilloma. Lesion composed of numerous glands lined by ciliated respiratory epithelium. 


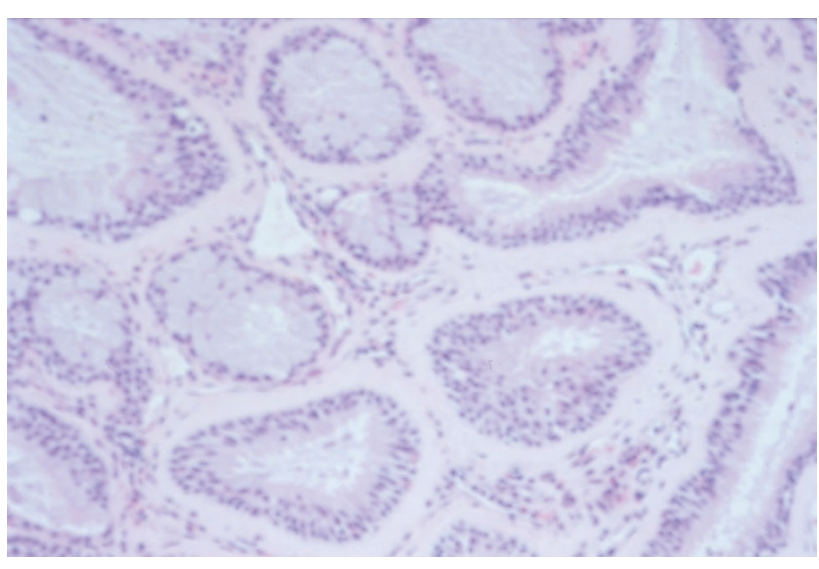

FIGURE 7. Respiratory epithelial adenomatoid hamartoma. Note that each gland is surrounded by a thick, eosinophilic basement membrane. Compare with Figure 4.

on the nasal septum, IPs arise almost exclusively on the lateral nasal wall in the vicinity of the middle turbinate and ethmoid sinus area. IPs are also composed predominantly of hyperplastic islands of squamous epithelium with few interspersed mucous (goblet) cells and a prominent intraepithelial component of neutrophils. Respiratory epithelium may also be seen but is usually not dominant. The basement membranes around the epithelial islands in IPs are also thin and delicate, not thick and hyalinized as seen in REAH. Mucoserous glands are also sparse to absent in IPs.

Adenocarcinomas are characterized by a back-toback arrangement of their glands, occasional nuclear pleomorphism, prominent mitotic activity, perineural invasion, and a desmoplastic response to stromal invasion. These features are not seen in REAH.

\section{Treatment and Prognosis}

Simple, but complete surgical excision is curative. Recurrences are practically nonexistent.

\section{INTESTINAL-TYPE ADENOCARCINOMA OF THE SINONASAL TRACT}

\section{Terminology}

Adenocarcinomas comprise $10-25 \%$ of all malignant tumors of the nasal cavity and paranasal sinuses (86-91). Many of these are readily recognized as being of mucoserous (minor salivary) gland origin and can be appropriately subclassified according to standard categories, such as adenoid cystic carcinoma, mucoepidermoid carcinoma, and so on. Others are less familiar and present histologic patterns that resemble adenocarcinoma of the colon or, in some instances, villous adenomas $(92,93)$. A few may even resemble normal small intestinal mucosa (94). Such tumors have been referred to by a variety of names, including colonic-type adenocarcinomas, mucinous adenocarcinomas, heterotopic tumors with intestinal mucous membrane, enterictype adenocarcinomas, papillary adenocarcinomas, or nonspecific adenocarcinomas. The term that has currently emerged as the most preferred is intestinal-type adenocarcinoma (ITAC).

\section{Etiology}

Although ITACs are uncommon, they have generated interest not only because of their unusual histologic appearance but also, epidemiologically, as a result of their association with occupational exposure to wood and, occasionally, leather dust (95-109).

The tumor came into prominence in the 1960s when Hadfield astutely observed an increased incidence of adenocarcinomas of the sinonasal tract among woodworkers employed in the furniture industry of Oxfordshire and Buckinghamshire, England. Hadfield's observation was initially reported by a colleague, Macbeth, in 1965 and subsequently verified by others (110-114). It soon became apparent that the risk for developing ITAC was not limited to these geographic areas but also involved woodworkers in many other countries $(98,99,102$, 104, 106, 108, 115, 116, 118).

In a review of 5785 patients with sinonasal malignant tumors from 17 countries, Mohtashamipur et al. (99) observed that $23 \%$ were woodworkers and, of these, $64 \%$ had adenocarcinomas. The risk for developing ITAC in the furniture worker exposed to wood dust is $70-500$ times that of the nonwoodworker $(95,109)$. Dust particles $\geq 5 \mu \mathrm{m}$ in size and primarily from the hardwood trees beech, oak, and mahogany are thought to be responsible for the tumor, rather than the lacquers, varnishes, and adhesives applied to the furniture. The inhaled particles are concentrated in the anterior portion of the nasal septum and middle turbinate, where they induce cuboidal or squamous metaplasia with impairment of the mucociliary clearance mechanism $(112,119)$. This results in prolonged mucosal contact of the dust.

The carcinogen in wood dust still has not been identified. Speculation has centered on (1) simple chronic mechanical irritation of the dust particles; (2) intrinsic chemical substances normally present in wood such as alkaloids, saponins, resins, fungal proteins, and so on; and/or (3) extrinsic chemicals (pesticides and preservatives) applied to trees, during growth and harvesting.

The average interval from first dust exposure to the appearance of ITAC is 40 years (range, 7-69 years) (99). The length of dust exposure has been highly variable. In one of Hadfield's original patients, the length of exposure was only 18 months 
(112). This, however, seems to be a singular experience. The length of dust exposure in other studies has ranged from 5 to 55 years (105). The risk for ITAC does not appear to decrease for at least 15 years (maybe more) after termination of occupational exposure (120).

Although the majority of tumors associated with wood dust exposure are ITACs, there is also an increased incidence of squamous cell carcinomas, especially among woodworkers in Japan (121). Interestingly, in contrast with ITACs, which are associated with hard wood exposure, squamous cell carcinomas and undifferentiated carcinomas are more common in individuals exposed to dust from soft woods (pine and spruce) $(105,122)$.

It has also been suggested that workers with an occupational exposure to wood dust may also be at risk for developing other malignancies. Among these are Hodgkin's disease and carcinomas of the skin, gastrointestinal tract, and lungs, to mention a few $(99,105)$.

\section{Clinical Features}

ITAC can be divided clinically into two categories: those related to occupational exposure $(\mathrm{O}$ ITAC) and those that occur sporadically (S-ITAC) without a known history of occupational exposure. There may be differences between the two. According to Barnes (123), O-ITAC arises primarily in the nasal cavity and ethmoid sinus region, and $85-95 \%$ of patients are men. The male predominance is probably related to the fact that very few women are employed as woodworkers. S-ITAC, on the other hand, may also occur in the same site(s) as the $\mathrm{O}$-ITAC but is relatively more common in the maxillary sinus. In addition, S-ITAC occurs equally between the two sexes. The average age at diagnosis for both types is about 58 years (range, 12-86 years).

Although almost all ITACs occur in the sinonasal tract, they are not unique to this site. Spiro et al. (124) have described three arising in the oral cavity: one in the palate, one in the floor of the mouth, and one in the cheek-lip area. Lopez and Perez (125) have also reported another case in the pharynx.

The most common presenting symptom is unilateral nasal obstruction, followed by epistaxis and purulent or clear rhinorrhea (92, 123, 126-130). Larger, more extensive tumors may result in facial pain, mass of the cheek, proptosis, and visual and/or neurologic symptoms. Cervical lymph node and distant metastases are rarely present at the time of initial presentation.

On physical exam, the tumors are polypoid, papillary, or nodular and dark red, gray-white, or pinkgray. Most are friable. Some are ulcerated and hemorrhagic, whereas others are mucoid.
Barnes (123) has described one patient with an advanced tumor of the maxillary sinus that was associated with a pretreatment borderline abnormal serum level of carcinoembryonic antigen. Whether this laboratory test has any role in monitoring the course of the disease is uncertain.

\section{Radiography}

Radiologic studies are essential in determining the extent of disease and the operative approach. Early lesions will show only a soft tissue mass with little, if any, evidence of bone destruction. Other tumors may be associated with considerable osteodestruction and invasion of contiguous structures such as the orbit and cranial cavity. A few may even involve the contralateral sinonasal tract.

As the tumor enlarges, it may interfere with drainage of nearby sinuses. The ensuing obstructive sinusitis then may interfere with optimal preoperative evaluation and staging.

\section{Pathology}

Several histological classifications of ITACs have been proposed $(117,123,130,131)$. The one proposed by Kleinsasser and Schroeder, however, seems to be gaining acceptance for its ease of use, reproducibility, and clinical correlation (132). According to them, ITACs can be subclassified into four categories: papillary tubular cylinder cell (PTCC), alveolar goblet cell, signet ring cell, and transitional. They further divided their PTCC variant into three additional subtypes: I (well differentiated), II (moderately differentiated), and III (poorly differentiated). In a collective review of 152 ITACs either initially classified and/or reclassified according to this scheme, 27 (18\%) were PTCC I, 54 (36\%); PTCC II, 31 (20\%); and PTCC III, 19 (13\%) alveolargoblet cell, 5 (3\%) signet ring cell, and 16 (11\%) transitional (123, 131-133).

The PTCC I (well differentiated, also known as papillary type) is characterized by fibrovascular fronds and glands (tubules) covered and/or lined by tall nonciliated, columnar (cylinder) cells (Fig. 8). The columnar cells may be polarized, with their long axes perpendicular to the basement membrane, or stratified and crowded. These cells have pink cytoplasm and round to oval nuclei that vary from vesicular to hyperchromatic, with or without nucleoli. In some tumors, goblet cells are found admixed with columnar cells in a ratio similar to that seen in the intestine. In others, the fronds may be covered exclusively by columnar or goblet cells. Mitoses may or may not be prominent. The background of papillary tumors is often 'dirty,' appearing hemorrhagic, necrotic, and inflammatory. 


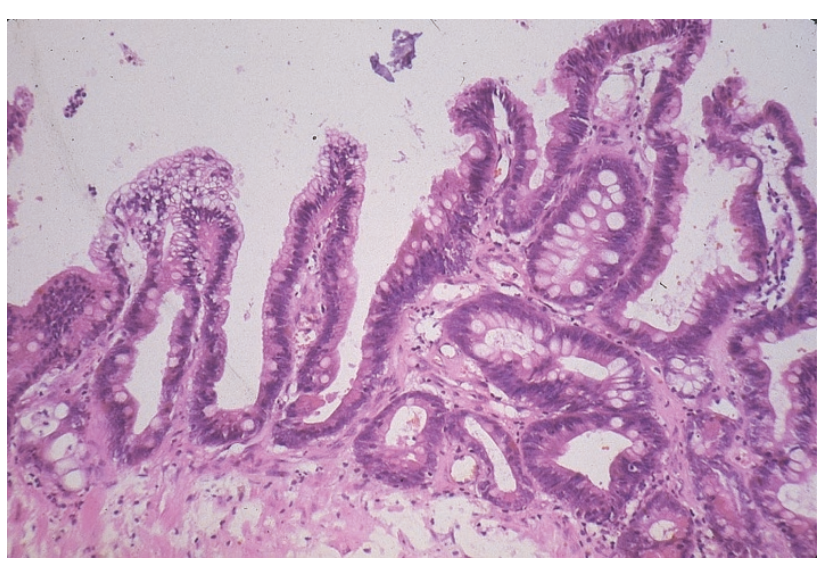

FIGURE 8. Intestinal-type adenocarcinoma. Papillary tubular cylinder cell-I variant (papillary type).

Although some papillary tumors are clearly invasive, others remain noninvasive (in situ) over a broad front much like papillary urothelial carcinoma in situ of the urinary bladder. A few are rather bland cytologically and may resemble a villous adenoma or even normal intestinal mucosa, yet are locally aggressive and destructive.

The PTCC II (moderately differentiated, also known as the colonic type) is composed of well to moderately differentiated glands and more closely resembles adenocarcinoma of the large intestine than does any of the other variants (Fig. 9). At times, one may also see cystic (glandular) spaces with intracystic papillary projections.

The PTCC III (poorly differentiated, also know as the solid type) is composed of a diffuse proliferation of smaller, more cuboidal cells with amphophilic to pink cytoplasm, occasionally with mucin droplets, and round, vesicular nuclei, often with nucleoli. There is little attempt at gland formation.

The alveolar-goblet cell (also known as mucinous type) is characterized by glands distended with mucus or individual glands and/or strips of epithelium with admixed goblet cells lying in pools of mucus (Fig. 10).

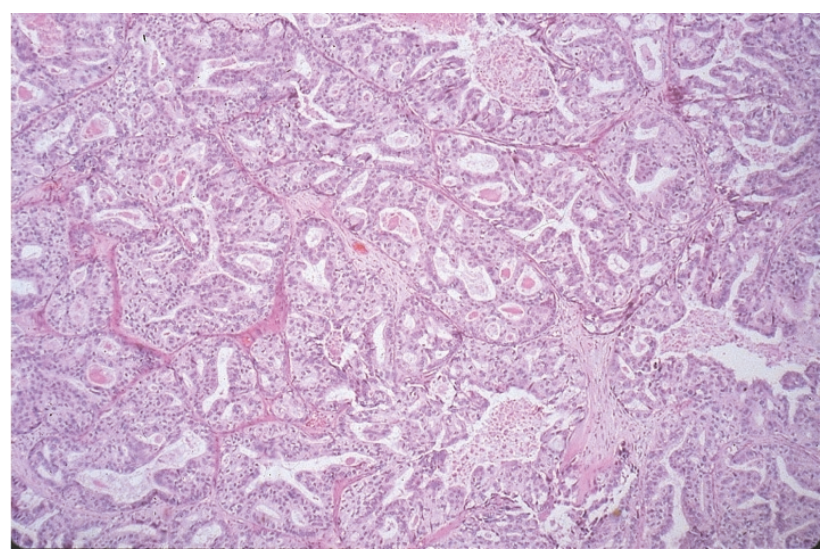

FIGURE 9. Intestinal-type adenocarcinoma. Papillary tubular cylinder cell-II variant (colonic type).

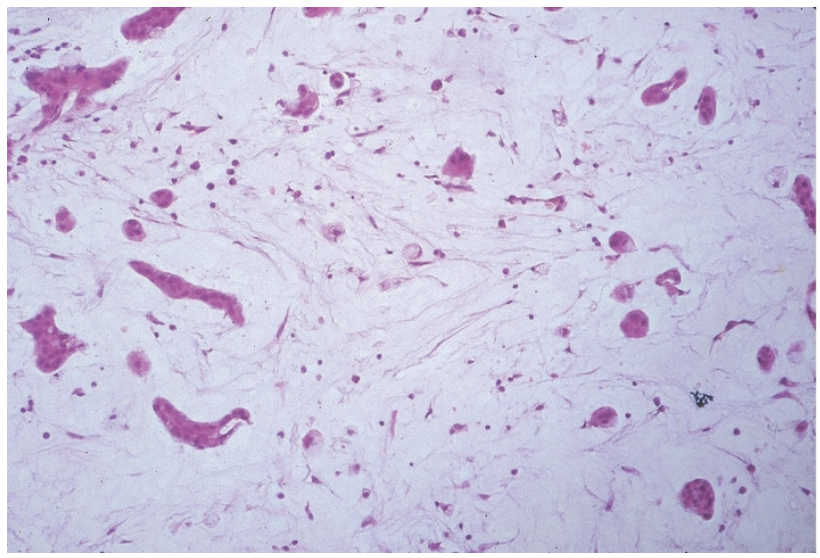

FIGURE 10. Intestinal-type adenocarcinoma. Alveolar-goblet cell variant (mucinous type).

The signet ring variant (also known as mucinous type) is composed of small groups or isolated signet ring cells floating in pools of mucus. No strips of epithelium are apparent.

The transitional cell type (also known as mixed type) is composed of two or more of the preceding growth patterns.

ITAC, regardless of histologic type, may contain Paneth and enterochromaffin cells as well as a muscularis mucosa. The enterochromaffin cells may express a variety of peptides, including gastrin, glucagon, serotonin, cholecystokinin, and leu-enkephalin $(93,126,127)$. Although Schmid et al. (93) describe an ITAC that was associated with an elevated serum level of somatostatin, these tumors virtually never produce a clinically significant endocrine syndrome.

Recurrent ITACs may manifest the histologic identity of the original tumor or they may recur and/or convert into another histologic pattern. If they do transform, the transformation is usually to one of the more aggressive types.

The most common histologic types of ITACs seen in woodworkers, as well as in sporadic cases, are the PTCC variants $(123,132)$.

ITAC, particularly the PTCC I, clearly arises from the mucosa of the sinonasal tract $(123,124,134,135)$. Whether others also arise from the mucosa or from mucoserous glands and/or their ducts is uncertain. On the basis of the work of Cheng and Leblond and of Kirkland, it has been suggested that multidirectional differentiation of a common stem cell could account for the variety of cells (Paneth, endocrine, absorptive, goblet) observed in ITAC $(94,136,137)$. The stem cell, either by direct transformation or by induction of adjacent mesenchyme, might also give rise to the muscularis mucosa noted in a few tumors.

The similarity of ITAC to intestinal tumors extends beyond the light-microscopic to the ultrastructural and, to some extent, the immunohisto- 
chemical level $(93,94,126,138)$. Batsakis et al. (126) observed glycocalyceal bodies in their ultrastructural evaluation of an ITAC of the nasal cavity. These structures are thought to be important in identifying tumors of intestinal epithelium or tumors arising from metaplastic intestinal-type epithelium. The immunohistochemical profile of ITAC is discussed in the next section of this article.

Although ITAC and colorectal adenocarcinoma are histologically similar, Wu et al. (139) have found important differences at the genetic level based on expression of K-ras-2 and p53. In contrast to colorectal adenocarcinoma, which demonstrates K-ras- 2 mutation in about $50 \%$ of cases, ITACs show no evidence of this mutation. Wu et al. also noted that only $18 \%$ of ITACs show p53 mutations, compared with $>75 \%$ observed in colorectal adenocarcinomas (139).

\section{Differential Diagnosis}

The differential diagnosis includes a metastasis from a gastrointestinal carcinoma, papillary rhinosinusitis, and papillary adenocarcinoma of the nasopharynx.

Metastases to the nasal cavity and paranasal sinuses from a primary adenocarcinoma of the gastrointestinal tract are not common $(140,141)$. In a study of 82 tumors metastatic to the maxilla, nose and paranasal sinuses, Bernstein et al. (140) found the most common sites to be the kidney (40 cases), lung (10 cases), breast (8 cases), testis ( 6 cases), gastrointestinal tract (5 cases; 2 stomach, 2 colon, and 1 rectum), uterus (4 cases), thyroid (3 cases), adrenals (2 cases), cutaneous melanoma ( 2 cases), and pancreas ( 2 cases). The maxillary, ethmoid, and frontal sinuses and nasal cavity were involved in descending order. In some of these patients, the head and neck metastasis was the initial manifestation of an otherwise clinically occult carcinoma. For this reason, examination of the gastrointestinal tract in all patients with ITAC, especially the PTCC II (colonic) variant, would seem prudent, although in the absence of relevant signs and symptoms, such studies will generally prove negative.

Immunohistochemical stains for chromogranin, neuron-specific enolase (NSE), and carcinoembryonic antigen (CEA) may offer some limited help in distinguishing ITAC from metastatic colorectal adenocarcinoma. Because ITACs tend to contain more endocrine cells than colorectal adenocarcinomas, they will usually show a more diffuse and stronger intensity when stained for chromogranin and NSE (138). In contrast, colorectal adenocarcinomas are diffusely and strongly positive for CEA, whereas ITACs tend to show only focal, weak reactivity (138).
Staining for cytokeratin 7 is also helpful in distinguishing ITAC from metastatic adenocarcinoma of the colon (142). ITAC is consistently positive for this marker, whereas adenocarcinoma of the colon is negative.

Sinusitis, at times, may have a papillary configuration, but in these instances, the papillae are short and blunt and not highly branched, as one sees in some ITACs. In addition, the background is 'clean' in papillary rhinosinusitis, the basement membrane is often thick and hyalinized, the surface cells are ciliated and free of dysplastic changes, and the stroma often has a prominent component of eosinophils.

Distinguishing P-ITAC from papillary adenocarcinoma of nasopharynx (PACN) may be more problematic. P-ITAC, in contrast to PACN, occurs primarily in the nasal cavity and paranasal sinuses and is often (not invariably) associated with an occupational exposure to wood dust. P-ITAC also tends to be less glandular and more papillary. Rather than cuboidal cells, the papillae are covered by tall columnar and goblet cells, the latter of which are sparse to absent in PACN. P-ITAC may also contain Paneth cells and scattered endocrine cells that may express somatostatin, gastrin, serotonin, and/or other secretory substances on appropriate staining. Such cells are not seen in PACP. Last, PACP tends to be associated with a hemorrhagic, inflammatory background and often recurs after therapy. PACP, in contrast, has a 'clean' background and rarely recurs.

\section{Treatment and Prognosis}

The clinical course of ITAC is characterized by repeated local recurrences $(53 \%)$ with ultimate invasion of the orbit and cranial cavity but little tendency toward cervical lymph node (mean, 8\%; range, $0-22 \%$ ) and systemic metastasis (mean, $13 \%$; range, $0-29 \%$ ) (38). Tumor necrosis with sepsis is often a problem and may be life threatening. In a review of 213 ITACs, Barnes noted that at least $60 \%$ of the patients were known to have died of their disease (123). Of those dying, $80 \%$ did so within 3 years of diagnosis. Some patients, especially those with PTCC I, may have a slow, 'smoldering' disease, only to die of their tumor 10 or more years later.

The 3-year cumulative survival rates according to histological type are $82 \%$ for PTCC I, $54 \%$ for PTCC II, 36\% for PTCC III, $48 \%$ for alveolar-goblet cell, $0 \%$ for signet ring cell, and $71 \%$ for transitional (132).

Perez et al. (143) studied 31 patients with adenocarcinomas of the ethmoid sinus (25 of which had been in contact with wood dust for 3-50 years) for the presence of ras gene mutations. $\mathrm{H}$-ras was found to be mutated in $5(16 \%)$ cases and was associated with a poor prognosis. The metastasis, however, could not be correlated with tumor stage, 
histologic type, or the patient's previous exposure to wood dust.

Treatment consists of surgical excision using a lateral rhinotomy or, at times, even a cranial base approach. The use of radiotherapy is dictated by the extent and resectability of the tumor. An elective neck dissection is not warranted.

Prognosis depends on the histologic type, degree of differentiation, stage of the disease, and the adequacy of resection margins. PTCC I has the best prognosis. It may recur but rarely metastasizes. The other types are more virulent, with a greater propensity for dissemination. Over the course of time, a few tumors may change from one histologic type into another. This may be an ominous finding, signaling a tumor with increased aggressiveness.

Woodworkers seem to have a better prognosis than those individuals with sporadic ITAC. This probably relates to the fact that the woodworker is under heightened surveillance for this tumor and that in this group, the tumors are more often found in the nasal cavity or ethmoid sinus and can therefore be detected earlier by the patient. In contrast, patients with sporadic tumors are not in early detection programs and have neoplasms that are relatively more common in the maxillary sinus, which are difficult to detect early.

\section{PAPILLARY ADENOCARCINOMA OF THE NASOPHARYNX}

\section{Terminology}

The vast majority of malignant tumors of the nasopharynx are either keratinizing or nonkeratinizing squamous cell carcinomas or malignant lymphomas $(144,145)$. Adenocarcinomas are uncommon, constituting $\leq 6 \%$ of all malignancies; and, of these, most are derived from the mucoserous (minor salivary) glands and can be classified according to standard categories (adenoid cystic carcinoma, mucoepidermoid carcinoma, and so on) (144). Exceptionally, adenocarcinomas may also arise from the mucosa, and when they do, they are typically papillary and are referred to as papillary adenocarcinomas of the nasopharynx (146, 147).

\section{Clinical Features}

PACN are slightly more common in males $(60 \%)$ and occur in individuals from 11 to 64 years of age (median, 33 years) $(146,147)$. Most present with airway obstruction. Other less common symptoms include serous otitis media with or without hearing loss and postnasal drip with blood-tinged sputum. Rarely the tumor may be an incidental finding after adenoidectomy.
PACN are typically confined to the nasopharynx and, on physical examination, present as exophytic or pedunculated masses with a papillary, nodular, or cauliflower-like appearance. The tumors range from 0.3 to $4.0 \mathrm{~cm}$ and most often involve the roof, lateral, or posterior walls of the nasopharynx.

There are no known risk factors associated with the development of this tumor. None of the patients thus far has had a significant history of tobacco or alcohol abuse or occupational, environmental, or radiation exposure (146).

\section{Pathology}

The tumors arise from the surface epithelium of the nasopharynx and may remain in situ or become invasive. They are characterized by papillary and glandular growth patterns (Fig. 11). The papillae have fibrovascular cores and often show arborization, whereas the glands have a back-to-back, often cribriform arrangement. Both papillae and glands are covered or lined by one or more layers of cuboidal to columnar cells with pink cytoplasm and round to oval nuclei that vary from hyperchromatic to optically clear. Mild to moderate nuclear pleomorphism may be seen, but nucleoli, mitoses, and necrosis are uncommon. A few tumors may also contain psammoma bodies. Vascular, lymphatic, or neural invasion are not seen.

PACN typically contain periodic acid-Schiff, diastase-resistant intracytoplasmic granules and stain focally positive for intracellular or luminal mucin (146). They are also diffusely reactive for cytokeratin and epithelial membrane antigen and focally positive for carcinoembryonic antigen. They are negative for glial fibrillary acidic protein, S-100 protein, and thyroglobulin.

\section{Differential Diagnosis}

The differential diagnosis includes papillary thyroid carcinoma, papillary variant of intestinal-type

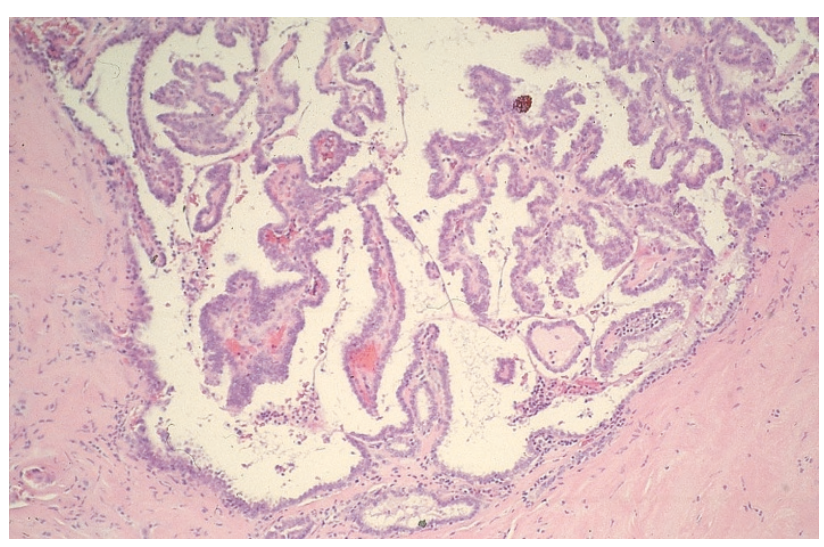

FIGURE 11. Papillary adenocarcinoma of the nasopharynx. The tumor is composed of both papillae and glands and arises from the mucosa of the nasopharynx. 
adenocarcinoma (P-ITAC), and low-grade papillary adenocarcinoma of salivary gland origin (LGPASO).

Because of the papillae and the occasional presence of psammoma bodies and optically clear nuclei, PACN can easily be mistaken for metastatic papillary thyroid carcinoma. PACN, however, are negative for thyroglobulin and will typically show dysplasia or in situ changes of the surface epithelium.

Distinguishing P-ITAC from PACN may be more problematic $(123,125)$. P-ITAC, in contrast to PACN, occurs primarily in the nasal cavity and paranasal sinuses and is often (not invariably) associated with an occupational exposure to wood dust. P-ITAC also tends to be less glandular and more papillary. Rather than cuboidal cells, the papillae are covered by tall columnar and goblet cells, the latter of which are sparse to absent in PACN. P-ITAC may also contain Paneth cells and scattered endocrine cells that may express somatostatin, gastrin, serotonin, and/or other secretory substances on appropriate staining. Such cells are not seen in PACP. Last, PACP tends to be associated with a hemorrhagic, inflammatory background and often recurs after therapy. PACP, in contrast, has a 'clear' background and rarely recurs.

LGPASO occurs almost exclusively in the oral cavity, especially the palate $(148,149)$. Furthermore, it arises submucosally from minor salivary glands rather than from the surface, as does the PACN. Staining for S-100 protein may also be helpful. Thus far, PACN have been S-100 protein negative, whereas LGPASO are usually positive (146, 150). LGPASO are also more aggressive, with frequent local recurrence $(27 \%)$, and, at times, lymph node metastasis (17\%) (150).

\section{Treatment and Prognosis}

PACN is a slow-growing, indolent neoplasm that rarely recurs and has thus far not metastasized to either cervical lymph nodes or more distant sites. The treatment of choice is surgery, using a transpalatal approach. Wenig et al. (146) describe one case that was treated initially with full-course radiotherapy. The tumor recurred within months after treatment. The patient subsequently underwent surgical excision and was reported free of disease 11 years later. This singular experience certainly casts doubts on the efficacy of radiation therapy.

\section{LOW-GRADE PAPILLARY ADENOCARCINOMA OF THE TEMPORAL BONE}

\section{Terminology}

In 1988, Gaffey et al. (151) described a 29-yearold woman with a histologically bland but locally destructive tumor of the temporal bone and reviewed nine similar cases identified retrospectively in the English language literature. The authors speculated that the tumor arose from the middle ear mucosa and proposed the term aggressive papillary middle ear tumor.

As experience with the tumor accumulated, it became apparent that the middle ear was not always involved, thus casting doubt on its alleged origin from this site (152). In a review of 20 additional cases, Heffner (153) concluded that the tumor actually arose from the endolymphatic sac and only secondarily involved the middle ear. He, therefore, suggested the term low-grade adenocarcinoma as being more appropriate because it called attention to its potential aggressive behavior and eliminated all reference to the previous misconception that it arose from the middle ear.

Other names that have been applied to this tumor include papillary adenoma $(154,155)$, aggressive papillary tumor (156), low-grade papillary adenomatous tumor (157), endolymphatic sac tumor (158, 159), Heffner's tumor (160, 161), adenocarcinoma (162-167), and papillary adenocarcinoma (168). In this review, low-grade papillary adenocarcinoma (LGPA) will be used.

\section{Clinical Features}

LGPA is a slowly growing, locally aggressive tumor of the temporal bone that has been described in patients from 15-71 years of age (average, 41 years) $(151,153)$. It affects both sexes about equally. In a collective review of 30 cases, 13 occurred in males and 17 in females $(151,153)$.

There is no significant lateralization of the tumor to either side of the body. Of 20 cases in which the side of origin was indicated, 8 involved the right ear, 11 the left ear, and in the remaining case, the side was not indicated (153). Bilateral lesions, either synchronous or asynchronous, have been described but are exceptional and should always arouse suspicion of von Hippel-Lindau disease (see discussion later in this article) (156).

Unilateral hearing loss (usually sensorineural, occasionally conductive, rarely mixed), tinnitus, otitis, and/or vertigo of 6 months to 22 years duration are the usual presenting symptoms. Some also manifest with facial nerve paralysis.

Physical examination may be unremarkable or may reveal a blue or red mass behind an intact, sometimes perforated tympanic membrane. Occasionally the tumor may even project into the external auditory canal (159).

\section{LGPA and von Hippel-Lindau Disease}

Von Hippel-Lindau disease (VLD) is an autosomal-dominant disorder characterized by a variety of abnormalities, chief of which include he- 
mangioblastomas of the retina, cerebellum, medulla oblongata, and spinal cord; hemangiomas of the liver and kidney; renal cell carcinoma; and cysts of the pancreas and kidney. Linkage studies have mapped the VLD gene to the short arm of chromosome 3 , and a mutated tumor suppressor gene has been identified in both normal and neoplastic tissue from VLD patients $(169,170)$.

Recently, it has been shown that LGPA may be another, albeit infrequent, manifestation of VLD (154, 156, 159, 171). According to Gaffey et al., $\geq 15 \%$ of all LGPAs are associated with VLD (171). This is especially so if the tumors are bilateral (159).

\section{Radiography and Angiography}

Radiologic studies typically show a lytic temporal bone lesion, often with extension into the posterior cranial cavity, manifesting as a cerebellopontine angle neoplasm (153). The epicenter of the lesion lies at or near the posterior-medial surface of the temporal bone.

According to Megerian et al. (159), LGPA may extend along four pathways from its endolymphatic sac origin. In order of frequency, they generally progress (1) posteriorly to the cerebellopontine angle and posterior fossa, (2) laterally via the mastoid cell tract to the middle ear and external auditory canal, (3) superiorly toward and into the middle cranial fossa, and (4) medially along the petrous ridge to the clivus and cavernous and sphenoid sinuses.

Angiograms show the tumor to be highly vascular with a dual extracranial and intracranial blood supply (151). As a result, it is often mistaken for a jugulotympanic paraganglioma.

\section{Pathology}

Histologically, the tumor is composed of papillarycystic components (Fig. 12). The papillae are well

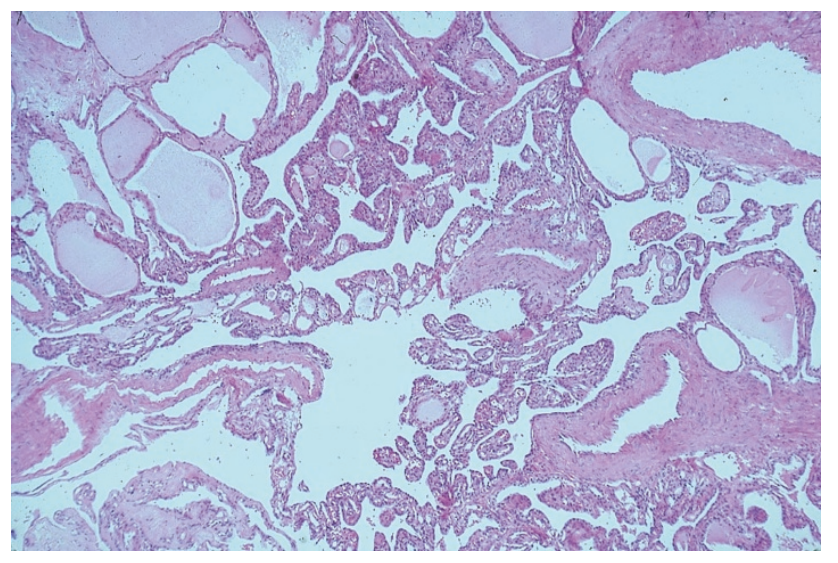

FIGURE 12. Low-grade papillary adenocarcinoma of the middle ear. The glands contain colloid-like secretions. vascularized and covered by a single layer of cuboidal cells, which have clear to pink cytoplasm and uniform round nuclei. Cellular pleomorphism and mitoses are absent. The cystic spaces characteristically contain pink colloid-like material, imparting a thyroid-like appearance. The secretory material is strongly positive with the periodic acid-Schiff stain and negative with mucicarmine. Areas of closely packed glands, fibrosis, hemorrhage, and cholesterol clefts may also be seen.

The epithelial cells contain glycogen but no intracytoplasmic mucin. On immunostaining, they are strongly positive for keratin; variably positive for S-100 protein ( $20-61 \%$ positive), glial fibrillary acidic protein (20-40\% positive), and synaptophysin $(30 \%$ positive); and negative for thyroglobulin $(153,172)$. The cells are also usually positive for epithelial membrane antigen, NSE, and vimentin.

\section{Differential Diagnosis}

The differential diagnosis includes middle ear adenoma, jugulotympanic paraganglioma, metastatic papillary thyroid carcinoma and renal cell carcinoma, and choroid plexus papilloma-carcinoma.

Middle ear adenomas are not papillary and do not invade or destroy bone as one sees in LGPA. Because of its hypervascularity on angiogram, LGPA is often confused clinically for a jugulotympanic paraganglioma (JTPG). JTPGs are not papillary-cystic, and LGPAs do not show the characteristic 'Zellballen' arrangement of cells as one sees in a JTPG. In addition, LGPA is keratin-positive, whereas the JTPG is keratin negative.

Metastatic papillary carcinoma of the thyroid can be excluded by the fact that LGPAs are negative for thyroglobulin and do not show the nuclear characteristics of papillary thyroid carcinoma ('ground glass' nuclei, nuclear grooves, nuclear inclusions of cytoplasm).

Metastatic renal cell carcinoma may be the most difficult entity to exclude, especially because both LGPA and renal cell carcinoma can contain clear cells, glycogen, and papillary-cystic areas. Immunohistochemical stains may offer some help. LGPAs are sometimes positive for S-100 protein (20-61\%), glial fibrillary acidic protein (20-40\%), and synaptophysin $(30 \%)(153,172)$. Renal cell carcinomas are negative for glial fibrillary acidic protein and synaptophysin and, according to Medeiros et al. (173), only $2 \%$ are positive for S-100 protein. Perhaps the best way to distinguish between the two is to obtain a computerized tomogram of the kidneys.

Choroid plexus papilloma and carcinoma almost always originate within the ventricles of the brain, whereas LGPAs are typically extradural. Staining for transthyretin may also be helpful. According to Megerian et al. (172), LGPAs are characteristically negative, or at most, weakly positive for this marker, 
whereas choroid plexus lesions are positive. Otherwise, there is too much overlap in immunohistochemical stains (keratin, epithelial membrane antigen, NSE, glial fibrillary acidic protein, and vimentin) to allow one to distinguish between these two neoplasms with confidence (174-179). Knowledge of the clinical and radiologic findings may be the best way to separate LGPA from a choroid plexus tumor.

\section{Treatment and Prognosis}

Complete surgical excision, if possible, is the treatment of choice. Radiation is largely untested but has been ineffective in the few cases in which it has been used (151).

Intraoperatively, the surgeon usually observes a blue, red, or white hypervascular, nonencapsulated lobular mass that often encases the ossicles and facial nerve. Though encased, the latter structures can often be dissected free without sacrifice. Bleeding may be profuse. Despite frequent intracranial extension, invasion of the brain has only been documented in one instance (151).

Of 30 cases contained in the reviews of Gaffey et al. (151) and Heffner (153), 70\% of the patients at last follow-up were alive with no evidence of disease, $7 \%$ were alive with disease, $13 \%$ were dead of disease, and $10 \%$ were lost to follow-up. Twenty percent of the patients experienced recurrence after initial attempts at excision. Although the tumor is rare and a large series of cases with long-term follow-up is not available, experience thus far indicates that LGPA is only a locally destructive tumor with little, if any, capacity to metastasize.

\section{REFERENCES}

1. Ward N. A mirror of the practice of medicine and surgery in the hospitals of London: London Hospital. Lancet 1854;2: $480-2$.

2. Hyams VJ. Papillomas of the nasal cavity and paranasal sinuses. A clinicopathologic study of 315 cases. Ann Otol Rhinol Laryngol 1971;80:192-206.

3. Snyder RN, Perzin KH. Papillomatosis of nasal cavity and paranasal sinuses (inverted papilloma, squamous papilloma). A clinicopathologic study. Cancer 1971;30:668-90.

4. Weissler MC, Montgomery WW, Turner PA, Montgomery SK, Joseph MP. Inverted papilloma. Ann Otol Rhinol Laryngol 1986;95:215-21.

5. Michaels L, Young M. Histogenesis of papillomas of the nose and paranasal sinuses. Arch Pathol Lab Med 1995;119: 821-6.

6. Lampertico P, Russell WO, MacComb WS. Squamous papilloma of the upper respiratory epithelium. Arch Pathol 1963;75:293-302.

7. Oberman HA. Papillomas of the nose and paranasal sinuses. Am J Clin Pathol 1964;42:245-58.

8. Vrabec DP. The inverted Schneiderian papilloma. A 25-year study. Laryngoscope 1994;104:582-605.
9. Fu YS, Hoover L, Franklin M, Cheng M, Cheng L, Stoler MH. Human papillomavirus identified by nucleic acid hybridization in concomitant nasal and genital papillomas. Laryngoscope 1992;102:1014-9.

10. Buchwald C, Franzmann M-B, Jacobsen GK, Lindeberg H. Human papillomavirus (HPV) in sinonasal papillomas: a study of 78 cases using in situ hybridization and polymerase chain reaction. Laryngoscope 1995;105:66-71.

11. Sarkar FH, Visscher DW, Kintanar EB, Zarbo RJ, Crissman JD. Sinonasal Schneiderian papillomas: human papillomavirus typing by polymerase chain reaction. Mod Pathol 1992;5:329-32.

12. Weiner JS, Sherris D, Kasperbauer J, Lewis J, Li H, Persing D. Relationship of human papillomavirus to Schneiderian papillomas. Laryngoscope 1999;109:21-6.

13. Norris HJ. Papillary lesions of the nasal cavity and paranasal sinuses. Part I. Exophytic (squamous) papillomas. A study of 28 cases. Laryngoscope 1962;72:1784-97.

14. Christensen WN, Smith RRL. Schneiderian papillomas. A clinicopathologic study of 67 cases. Hum Pathol 1986;17: 393-400.

15. Buchwald C, Franzmann M-B, Tos M. Sinonasal papillomas: a report of 82 cases in Copenhagen County, including a longitudinal, epidemiological and clinical study. Laryngoscope 1986;105:72-9.

16. Hirschfield LS, Harrison G. Human papillomavirus in sinonasal papillomas. Mod Pathol 1990;3:45A(abstract).

17. Judd R, Zaki SR, Coffield LM, Evatt BL. Sinonasal papillomas and human papillomavirus: human papillomavirus 11 detected in fungiform Schneiderian papillomas by in situ hybridization and the polymerase chain reaction. Hum Pathol 1991;22:550-6.

18. Kashima HK, Kessis T, Hruban RH, Wu TC, Zinreich SJ, Shah KV. Human papillomavirus in sinonasal papillomas and squamous cell carcinoma. Laryngoscope 1992;102:973-6.

19. McLaughlin CM, Kandel RA, Colgan TJ, Swanson DB, Witterick IJ, Ngan BY. Prevalence of human papillomavirus in sinonasal papillomas: a study using polymerase chain reaction and in situ hybridization. Mod Pathol 1992;5:406-9.

20. Wu T-C, Trujillo JM, Kasima HK. Association of human papillomavirus with nasal neoplasia. Lancet 1993;341:522-4.

21. Gaffey MJ, Frierson HF Jr, Weiss LM, Stoler MH. Prevalence of Epstein-Barr virus (EBV) and human papillomavirus (HPV) in sinonasal papillomas: an in situ hybridization (ISH) study. Lab Invest 1996;74:101A, (abstract).

22. Buchwald C, Franzman M-B, Jacobsen GK, Juhl BR, Lindeberg H. Carcinomas occurring in papillomas of the nasal system associated with human papilloma virus (HPV). Rhinology 1997;35:74-8.

23. Suh KW, Facer GW, Devine KD, Weiland LH, Zujko RD. Inverting papilloma of the nose and paranasal sinuses. Laryngoscope 1977;87:35-46.

24. Lawson W, Le Benger J, Som P, Bernard PJ, Biller HF. Inverted papilloma: an analysis of 87 cases. Laryngoscope 1989;99:1117-24.

25. Myers EN, Fernau JL, Johnson JT, Tabet JC, Barnes EL. Management of inverted papilloma. Laryngoscope 1990; 100:481-90.

26. Phillips PP, Gustafson RO, Facer GW. The clinical behavior of inverted papilloma of the nose and paranasal sinuses. Report of 112 cases and review of the literature. Laryngoscope 1990;100:463-9.

27. Outzen KE, Grontved A, Jorgensen K, Clausen PB. Inverted papilloma of the nose and paranasal sinuses: a study of 67 patients. Clin Otolaryngol 1991;16:309-12.

28. Dolgin SR, Zaveri VD, Casiano RR, Maniglia AJ. Different options for treatment of inverting papilloma of the nose and paranasal sinuses: a report of 41 cases. Laryngoscope 1992;102:231-6. 
29. Bielamowicz S, Calcaterra TC, Watson D. Inverting papilloma of the head and neck: the UCLA update. Otolaryngol Head Neck Surg 1993;109:71-6.

30. Lawson W, Ho BT, Shaari CM, Biller HF. Inverted papilloma: a report of 112 cases. Laryngoscope 1995;105:282-8

31. Eavey RD. Inverted papilloma of the nose and paranasal sinuses in childhood and adolescence. Laryngoscope 1985; 95:17-22.

32. Peters BW, O'Reilly RC, Willcox TO Jr, Rao VM, Lowry LD, Keane WM. Inverted papilloma isolated to the sphenoid sinus. Otolaryngol Head Neck Surg 1995;113:771-81.

33. Kelley JH, Joseph M, Carroll E, Goodman ML, Pilch BZ, Levinson RM, et al. Inverted papilloma of the nasal septum. Arch Otolaryngol 1980;106:767-71.

34. Wenig BM. Schneiderian-type mucosal papillomas of the middle ear and mastoid. Ann Otol Rhinol Laryngol 1996; 105:226-33.

35. Sulica RL, Wenig BM, Debo RF, Sessions RB. Schneiderian papillomas of the pharynx. Ann Otol Rhinol Laryngol 1999; 108:392-7.

36. Hampal S, Hawthorne M. Hypopharyngeal inverted papilloma. J Laryngol Otol 1990;104:432-4.

37. Astor FC, Donegan O, Gluckman JL. Unusual anatomic presentations of inverting papilloma. Head Neck Surg 1985; 7:243-5.

38. Ryan SJ, Font RL. Primary epithelial neoplasms of the lacrimal sac. Am J Ophthalmol 1973;76:73-88.

39. Fechner RE, Sessions RE. Inverted papilloma of the lacrimal sac, the paranasal sinuses and the cervical region. Cancer 1977;40:2303-8.

40. Respler DS, Jahn A, Pater A, Pater MM. Isolation and characterization of papillomavirus DNA from nasal inverting (Schneiderian) papillomas. Ann Otol Rhinol Laryngol 1987; 96:170-3.

41. Syrjanen S, Happonen R-P, Virolainen E, Siivonen L, Syrjanen K. Detection of human papillomavirus (HPV) structural antigens and DNA types in inverted papillomas and squamous cell carcinomas of the nasal cavities and paranasal sinuses. Acta Otolaryngol (Stockh) 1987;104:334-41.

42. Weber RS, Shillitoe EJ, Robbins KT, Luna MA, Batsakis JG, Donovan DT, et al. Prevalence of human papillomavirus in inverted nasal papillomas. Arch Otolaryngol Head Neck Surg 1988;114:23-6.

43. Brandwein M, Steinberg B, Thung S, Biller H, Dilorenzo T, Galli R. Human papillomavirus 6/11 and 16/18 in Schneiderian inverted papillomas. In situ hybridization with human papillomavirus RNA probes. Cancer 1989;63:1708-13.

44. Bryan RL, Bovan IS, Crocker J, Young LS. Detection of HPV 6 and 11 in tumours of the upper respiratory tract using the polymerase chain reaction. Clin Otolaryngol 1990;15:17780.

45. Klemi PJ, Joensuu H, Siivonen L, Virolainen E, Syrjanen S, Syrjanen K. Association of DNA aneuploidy with human papillomavirus-induced malignant transformation of sinonasal traditional papillomas. Otolaryngol Head Neck Surg 1989;100:563-7.

46. Siivonen L, Virolainen E. Transitional papilloma of the nasal cavity and paranasal sinuses. Clinical course, viral etiology and malignant transformation. ORL J Otorhinolaryngol Relat Spec 1989;51:262-7.

47. Ishibashi T, Tsunokawa Y, Matsushima S, Nomura Y, Sugimura T, Terada M. Presence of human papillomavirus type-6 related sequences in inverted nasal papillomas. Eur Arch Otorhinolaryngol 1990;247:296-9.

48. Furuta Y, Shinohara T, Sano K, Nagashima K, Inoue K, Tanaka K, et al. Molecular pathologic study of human papillomavirus infection in inverted papilloma and squamous cell carcinoma of the nasal cavities and paranasal sinuses. Laryngoscope 1991;101:79-85.
49. Beck JC, McClatchey KD, Lesperance MM, Esclamado RM, Carey TE, Bradford CR, et al. Presence of human papillomavirus predicts recurrence of inverted papilloma. Otolaryngol Head Neck Surg 1995;113:49-55.

50. Ogura H, Fujiwara T, Hamaya K, Saito R. Detection of human papillomavirus type 57 in a case of inverted nasal papillomatosis in Japan. Eur Arch Otorhinolaryngol 1995; 252:513-5.

51. Macdonald MR, Le KT, Freeman J, Hui MF, Cheung RK, Dosch H-M. A majority of inverted sinonasal papillomas carries Epstein-Barr virus genomes. Cancer 1995;75:230712.

52. Momose KJ, Weber AL, Goodman M, Macmillan AS Jr, Roberson GH. Radiologic aspects of inverted papilloma Radiology 1980;134:73-9.

53. Norris HJ. Papillary lesions of the nasal cavity and paranasal sinuses. Part II. Inverting papillomas. A study of 29 cases. Laryngoscope 1963;73:1-17.

54. Abildgaard-Jensen J, Greisen O. Inverted papillomas of the nose and the paranasal sinuses. Clin Otolaryngol 1985;10: 135-43.

55. Myers EN, Schramm VL Jr, Barnes EL Jr. Management of inverted papillomas of the nose and paranasal sinuses. Laryngoscope 1981;91:2071-84.

56. Skolnik EM, Loewy A, Friedman JE. Inverted papilloma of the nasal cavity. Arch Otolaryngol 1966;84:83-9.

57. Lasser A, Rothfeld PR, Shapiro RS. Epithelial papilloma and squamous cell carcinoma of the nasal cavity and paranasal sinuses. A clinicopathologic study. Cancer 1976;38:2503-10.

58. Woodson GE, Robbins KT, Michaels L. Inverted papilloma. Considerations in treatment. Arch Otolaryngol 1985;111: 806-11.

59. Segal K, Atar E, Mor C, Har-El G, Sidi J. Inverting papilloma of the nose and paranasal sinuses. Laryngoscope 1986;96: 394-8.

60. Lesperance MM, Esclamado RM. Squamous cell carcinoma arising in inverted papilloma. Laryngoscope 1995;105:17883.

61. Caruana SM, Zwiebel N, Cocker R, et al. P53 alteration and human papilloma virus infection in paranasal sinus cancer. Cancer 1997;79:1320-8.

62. Finkelstein SD, Tiffee JC, Bakker A, et al. Malignant transformation in sinonasal papillomas is closely associated with aberrant p53 expression. Mol Diag 1998;3:37-42.

63. Fang S-Y, Yan J-J, Ohyama M. Immunohistochemistry of p53 in sinonasal inverted papilloma and associated squamous cell carcinoma. Am J Rhinol 1998;12:119-24.

64. Ingle R, Jennings TA, Goodman ML, et al. CD44 expression in sinonasal inverted papillomas and associated squamous cell carcinoma. Am J Clin Pathol 1998;109:309-14.

65. Ellis GL, Auclair PL. Ductal papillomas. In: Ellis GL, Auclair PL, Gnepp DR, editors. Surgical pathology of the salivary glands. Philadelphia: Saunders; 1991. p. 238-51.

66. Van Olphen AF, Lubsen H, van't Verlaat JW. An inverted papilloma with intracranial extension. J Laryngol Otol 1988; 102:534-7.

67. Stankiewicz JA, Girgis SJ. Endoscopic surgical treatment of nasal and paranasal sinus inverted papilloma. Otolaryngol Head Neck Surg 1993;109:988-95.

68. Mendenhall WM, Million RR, Cassisi NJ, Pierson KK. Biologically aggressive papillomas of the nasal cavity: the role of radiation therapy. Laryngoscope 1985;95:344-7.

69. Ridolfi RL, Lieberman PH, Erlandson RA, Moore OS. Schneiderian papillomas: a clinicopathologic study of 30 cases. Am J Surg Pathol 1977;1:43-53.

70. Barnes L, Bedetti C. Oncocytic Schneiderian papilloma: a reappraisal of cylindrical cell papilloma of the sinonasal tract. Hum Pathol 1984;15:344-51. 
71. DeBoom GW, Jensen JL, Wuerker RB. Cylindrical cell papilloma. Oral Surg Oral Med Oral Pathol 1986;61:607-10.

72. Kusakari J, Hozawa K, Hanazima T, Suzuki S, Takasaka T, Sasano N. Clinical report: cylindrical cell papilloma of the paranasal sinus. Arch Otorhinolaryngol 1987;244:246-8.

73. Cunningham MJ, Brantley S, Barnes L, Schramm VL Jr. Oncocytic Schneiderian papilloma in a young adult: a rare diagnosis. Otolaryngol Head Neck Surg 1987;97:47-51.

74. Ward BE, Fechner RE, Mills SE. Carcinoma arising in oncocytic Schneiderian carcinoma. Am J Surg Pathol 1990;14: 364-9.

75. Kapadia SB, Barnes L, Pelzman K, Mirani N, Heffner DK, Bedetti C. Carcinoma ex oncocytic Schneiderian (cylindrical cell) papilloma. Am J Otolaryngol 1993;14:332-8.

76. Ferlito A, Devaney KO. Developmental lesions of the head and neck: terminology and biologic behavior. Ann Otol Rhinol Laryngol 1995;104:913-8.

77. Baille EE, Batsakis JG. Glandular (seromucinous) hamartoma of the nasopharynx. Oral Surg 1974;38:760-2.

78. Zarbo RJ, McClatchey KD. Nasopharyngeal hamartoma: report of a case and review of the literature. Laryngoscope 1983;93:494-7.

79. Graeme-Cook F, Pilch BZ. Hamartomas of the nose and nasopharynx. Head Neck 1992;14:321-7.

80. Terris MH, Billman GF, Pransky SM. Nasal hamartoma: case report and review of the literature. Int J Pediatr Otorhinolaryngol 1993;28:83-8.

81. Adair CF, Thompson LDR, Wenig BM, Heffner DK. Chondro-osseous and respiratory epithelial hamartomas of the sinonasal tract and nasopharynx [abstract]. Mod Pathol 1996;74:100A.

82. McDermott MB, Ponder TB, Dehner LP. Nasal chondromesenchymal hamartoma. An upper respiratory tract analogue of the chest wall mesenchymal hamartoma. Am J Surg Pathol 1998;22:425-33.

83. Hughes GB, Sharpino G, Hunt W, Tucker HM. Management of the congenital midline nasal mass: a review. Head Neck Surg 1980;2:222-3.

84. Coppit GL III, Perkins JA, Manning SC. Nasopharyngeal teratomas and desmoids: a review of the literature and case series. Int J Pediatr Otorhinolaryngol 2000;52:219-27.

85. Wenig BM, Heffner DK. Respiratory epithelial adenomatoid hamartomas of the sinonasal tract and nasopharynx: a clinicopathologic study of 31 cases. Ann Otol Rhinol Laryngol 1995;104:639-45.

86. Frazell EL, Lewis JS. Cancer of the nasal cavity and accessory sinuses. A report of the management of 416 patients. Cancer 1963;16:1293-301.

87. Bridger MWM, Beale FA Jr, Bryce DP. Carcinoma of the paranasal sinuses-a review of 158 cases. J Otolaryngol 1978;7:379-88.

88. Robin PE, Powell DJ, Stansbie JM. Carcinoma of the nasal cavity and paranasal sinuses: incidence and presentation of different histological types. Clin Otolaryngol 1979;4:431-56.

89. Weber AL, Stanton AC. Malignant tumors of the paranasal sinuses: radiological, clinical, and histopathological evaluation of 200 cases. Head Neck Surg 1984;6:761-76.

90. Sisson GA Sr, Toriumi DM, Atiyah RA. Paranasal sinus malignancy: a comprehensive update. Laryngoscope 1989;99: 143-50.

91. Le Q-T, Fu KK, Kaplan M, et al. Treatment of maxillary sinus carcinoma. A comparison of the 1997 and 1977 American Joint Committee on Cancer Staging Systems. Cancer 1999; 86:1700-11.

92. Sanchez-Casis G, Devine KD, Weiland LH. Nasal adenocarcinomas that closely simulate colonic carcinomas. Cancer 1971;28:714-20.
93. Schmid KO, Aubock L, Albegga K. Endocrine-amphicrine enteric carcinoma of the nasal mucosa. Virchows Arch Pathol Anat 1979;383:329-43.

94. Mills SE, Fechner RE, Cantrell RW. Aggressive sinonasal lesion resembling normal intestinal mucosa. Am J Surg Pathol 1982;6:803-9.

95. Roush GC. Epidemiology of cancer of the nose and paranasal sinuses: current concepts. Head Neck Surg 1979;2:311.

96. Muir CS, Nectoux J. Descriptive epidemiology of malignant neoplasms of nose, nasal cavities, middle ear and accessory sinuses. Clin Otolaryngol 1986;5:195-211.

97. Elwood JM. Wood exposure and smoking: association with cancer of the nasal cavity and paranasal sinuses in British Columbia. Can Med Assoc J 1981;124:1573-7.

98. Klintenberg C, Olofsson J, Hellquist H, Sokjer H. Adenocarcinoma of the ethmoid sinuses. A review of 28 cases with special reference to wood dust exposure. Cancer 1984;54: $482-8$.

99. Mohtashamipur E, Norpoth K, Luhmann F. Cancer epidemiology of woodworking. J Cancer Res Clin Oncol 1989;115: 503-15.

100. Finkelstein MM. Nasal cancer among North American woodworkers: another look. J Occup Med 1989;31:35-40.

101. Imbus HR. Nasal cancer in woodworkers [letter to the editor]. J Occup Med 1990;32:422-3.

102. Comba P, Battista G, Belli S, et al. A case-control study of cancer of the nose and paranasal sinuses and occupational exposures. Am J Ind Med 1992;22:511-20.

103. Luce D, Lecere A, Morcet J-F, et al. Occupational risk factors for sinonasal cancer: a case-control study in France. Am J Ind Med 1992;21:163-75.

104. Nunez F, Suarez C, Alvarez I, et al. Sinonasal adenocarcinoma: epidemiological and clinicopathological study of 34 cases. J Otolaryngol 1993;22:86-90.

105. Nylander LA, Dement JM. Carcinogenic effects of wood dust. Review and discussion. Am J Ind Med 1993;24:619-47.

106. Leclere A, Cortes MM, Gerin M, et al. Sinonasal cancer and wood dust exposure: results from a case-control study. Am J Epidemiol 1994;140:340-9.

107. Holt GR. Sinonasal neoplasms and inhaled air toxins. Otolaryngol Head Neck Surg 1994;111:12-4.

108. Blot WJ, Chow W-H, McLaughlin JK. Wood dust and nasal cancer risk. A review of the evidence from North America. JOEM 1997;39:148-56.

109. Acheson ED. Nasal cancer in the furniture, boat and shoe manufacturing industries. Prev Med 1976;5:295-315.

110. Macbeth R. Malignant disease of the paranasal sinuses. J Laryngol 1965;79:592-612.

111. Acheson ED, Cowdell RH, Hadfield E, Macbeth RG. Nasal cancer in woodworkers in the furniture industry. Br Med J 1968;2:587-96.

112. Hadfield EH. A study of adenocarcinoma of the paranasal sinuses in woodworkers in the furniture industry. Ann R Coll Surg Engl 1970;46:301-19.

113. Hadfield EH. Cancer of the nasal sinuses. Practitioner 1981; 225:1586-90.

114. Acheson ED, Winter PD, Hadfield E, Macbeth RG. Is nasal adenocarcinoma in the Buckinghamshire furniture industry declining? Nature 1982;299:263-5.

115. Brinton LA, Blot WJ, Stone BJ, Fraumeni JF Jr. A death certificate analysis of nasal cancer among furniture workers in North Carolina. Cancer Res 1977;37:3473-4.

116. Ceccehi F, Buiatti E, Kriebel D, et al. Adenocarcinoma of the nose and paranasal sinuses in shoemakers and woodworkers in the province of Florence, Italy. Br J Ind Med 1980;37:222-5. 
117. Ironside P, Matthews J. Adenocarcinoma of the nose and paranasal sinuses in woodworkers in the state of Victoria, Australia. Cancer 1975;36:1115-21.

118. Kawachi I, Pearse N, Fraser J. A New Zealand cancer registry-based study of cancer in wood workers. Cancer 1989;64:2609-13.

119. Wilhelmsson B, Lundh B. Nasal epithelium in woodworkers in the furniture industry. A histological and cytological study. Acta Otolaryngol 1984;98:321-34.

120. Hayes RB, Gerin M, Raatgever JW, de Bruyn A. Woodrelated occupations, wood dust exposure, and sinonasal adenocarcinoma. Am J Epidemiol 1986;124:569-77.

121. Shimizu H, Hozawa J, Saito H, et al. Chronic sinusitis and woodworking as risk factors for cancer of the maxillary sinus in northeast Japan. Laryngoscope 1989;99:58-61.

122. Boysen M, Voss R, Solberg LA. The nasal mucosa in soft wood exposed furniture workers. Acta Otolaryngol (Stockh) 1986;101:501-8.

123. Barnes L. Intestinal-type adenocarcinoma of the nasal cavity and paranasal sinuses. Am J Surg Pathol 1986;10:192202.

124. Spiro RH, Koss LG, Hajdu SI, Strong EW. Tumors of minor salivary gland origins. A clinicopathologic study of 492 cases. Cancer 1973;31:117-29.

125. Lopes JI, Perez A. Pharyngeal adenocarcinoma with intestinal features. J Laryngol Otol 1990;104:900-2.

126. Batsakis JG, Mackay B, Ordonez NG. Enteric-type adenocarcinoma of the nasal cavity. An electron microscopic and immunocytochemical study. Cancer 1984;54:855-60.

127. Urso C, Ninu MB, Franchi A, et al. Intestinal-type adenocarcinoma of the sinonasal tract: clinicopathologic study of 18 cases. Tumori 1993;79:205-10.

128. Salassa JR, McDonald TJ, Weiland LH. 'Colonic type' adenocarcinoma of the nasal cavity and paranasal sinuses. Otolaryngol Head Neck Surg 1980;88:133-5.

129. Boor A, Dudrikova K, Kavecansky V, Friedman I. Intestinaltype sinonasal adenocarcinoma: a sporadic case. J Laryngol Otol 1996;110:805-10.

130. Allessi DM, Trapp TK, Fu YS, Calcaterra TC. Nonsalivary sinonasal adenocarcinoma. Arch Otolaryngol Head Neck Surg 1988;114:996-9.

131. Franchi A, Gallo O, Santucci M. Clinical relevance of the histological classification of sinonasal intestinal-type adenocarcinoma. Hum Pathol 1999;30:1140-5.

132. Kleinsasser O, Schroeder H-G. Adenocarcinomas of the inner nose after exposure to wood dust. Morphological findings and relationships between histopathology and clinical behavior in 79 cases. Arch Otorhinolaryngol 1988;245:1-15.

133. Franquemont DW, Fechner RE, Mills SE. Histologic classification of sinonasal intestinal-type adenocarcinoma. Am J Surg Pathol 1991;15:368-75.

134. Gnepp DR, Heffner DR. Mucosal origin of sinonasal tract adenomatous neoplasms. Mod Pathol 1989;2:365-71.

135. Kleinsasser O, Schroeder H-G, Mayer-Brix J. Preinvasive stages of adenocarcinoma of the nose after exposure to wood dust. Eur Arch Otorhinolaryngol 1991;248:222-9.

136. Cheng H, Leblond CP. Origin, differentiation and renewal of four main epithelial types in the mouse small intestine. V. Unitarian therapy of the origin of the four epithelial cell types. Am J Anat 1974;141:537-61.

137. Kirkland SC. Clonal origin of columnar, mucous, and endocrine cell lineages in human colorectal epithelium. Cancer 1988;61:1359-63.

138. McKinny CD, Mills SE, Franquemont DW. Sinonasal intestina-type adenocarcinoma: immunohistochemical profile and comparison with colonic adenocarcinoma. Mod Pathol 1995;8:421-6.
139. Wu T-T, Barnes L, Bakker A, et al. K-ras-2 and p53 genotyping of intestinal-type adenocarcinoma of the nasal cavity and paranasal sinuses. Mod Pathol 1996;9:199-204.

140. Bernstein JM, Montgomery WW, Balogh K. Metastatic tumor to the maxilla and paranasal sinuses. Laryngoscope 1966;76:621-50.

141. Owa AO, Gallimore AP, Ajulo SO, Cheesman AD. Metastatic adenocarcinoma of the ethmoids in a patient with previous gastric adenocarcinoma: a case report. J Laryngol Otol 1995;109:751-9.

142. Krane JF, O'Connell JT, Pilch BZ, Faquin WC. Cytokeratin and mucin expression in intestinal-type sinonasal adenocarcinoma [abstract]. Mod Pathol 2000;13:139A.

143. Perez P, Dominquez O, Gonzalez S, et al. Ras gene mutations in ethmoid sinus adenocarcinoma. Prognostic implications. Cancer 1999;86:255-64.

144. Robin PE, Powell DJ, Holme GM. Malignant tumours of the nasopharynx: 220 cases 1957-1966. Clin Otolaryngol 1980; 5:139-56.

145. Resta L, Ricco R, Santangelo A. Morphologic and classificatory considerations about 140 cases of carcinoma of the nasopharynx. Tumori 1983;69:313-21.

146. Wenig BM, Hyams VJ, Heffner DK. Nasopharyngeal papillary adenocarcinoma. A clinicopathologic study of a lowgrade carcinoma. Am J Surg Pathol 1988;12:946-53.

147. van Hassett CA. Papillary adenocarcinoma of the nasopharynx. J Laryngol Otol 1991;105:853-4.

148. Mills SE, Garland TA, Allen MS Jr. Low-grade papillary adenocarcinoma of palatial salivary gland origin. Am J Surg Pathol 1984;8:367-74.

149. Fliss DM, Zirkin H, Puterman M, Tovi F. Low-grade papillary adenocarcinoma of buccal mucosa salivary gland origin. Head Neck 1989;11:237-41.

150. Mostofi R, Wood RS, Christison W, Talerman A. Low-grade papillary adenocarcinoma of minor salivary glands. Case report and review of the literature. Oral Surg Oral Med Oral Pathol 1992;73:591-5.

151. Gaffey MJ, Mills SE, Fechner RE, Intemann SR, Wick MR. Aggressive papillary middle-ear tumor. A clinicopathologic entity distinct from middle-ear adenoma. Am J Surg Pathol 1988;12:790-7.

152. Clarke TD. Aggressive middle ear tumor [letter to the editor]. Am J Surg Pathol 1989;13:985-6.

153. Heffner DK. Low-grade adenocarcinoma of probable endolymphatic sac origin. A clinicopathologic study of 20 cases. Cancer 1989;64:2292-302.

154. Palmer JM, Coker NJ, Harper RL. Papillary adenoma of the temporal bone in von Hippel-Lindau disease. Otolaryngol Head Neck Surg 1989;100:64-8.

155. Pollak A, Bohmer A, Spycher M, Fisch U. Are papillary adenomas endolymphatic sac tumors? Ann Otol Rhinol Laryngol 1995;104:613-9.

156. Poe DS, Tarlovec EC, Thomas CB, Kveton JF. Aggressive papillary tumors of temporal bone. Otolaryngol Head Neck Surg 1993;108:80-6.

157. Lavoie M, Morency RM. Low-grade papillary adenomatous tumors of the temporal bone: report of two cases and review of the literature. Mod Pathol 1995;8:603-8.

158. Li JC, Brackmann DE, Lo WWM, Carberry JN, House JW. Reclassification of aggressive adenomatous mastoid neoplasms as endolymphatic sac tumors. Laryngoscope 1993; 103:1342-8.

159. Megerian CA, McKenna MJ, Nuss RC, Maniglia AJ, Ojemann RG, Pilch BZ, et al. Endolymphatic sac tumors: histopathologic confirmation, clinical characterization and implication in von Hippel-Lindau disease. Laryngoscope 1995;105:801-8. 
160. Batsakis JG, El-Naggar AK. Papillary neoplasms (Heffner's tumors) of the endolymphatic sac. Ann Otol Rhinol Laryngol 1993;102:648-51.

161. El-Naggar AK, Pflatz M, Ordonez NG, Batsakis JG. Tumors of the middle ear and endolymphatic sac. Pathol Annu 1994;29(Part 2):199-229.

162. Pollanch JF, McDonald TG, Weiland LH, Facer GW, Harner SG. Adenocarcinoma and adenoma of the middle ear. Laryngoscope 1982;92:47-53.

163. Schuller DE, Conley JJ, Goodman JH, Clausen KP, Miller WJ. Primary adenocarcinoma of the middle ear. Otolaryngol Head Neck Surg 1983;91:280-3.

164. Goebel JA, Smith PG, Kemink JL, Graham MD. Primary adenocarcinoma of the temporal bone mimicking paragangliomas: radiographic and clinical recognition. Otolaryngol Head Neck Surg 1987;96:231-8.

165. Glasscock ME III, McKennan KX, Levine SC, Jackson G. Primary adenocarcinoma of the middle ear and temporal bone. Arch Otolaryngol Head Neck Surg 1987;113:822-4.

166. Carroll WR, Niparko JK, Zappia JJ, McClatchey KD. Primary adenocarcinoma of the temporal bone. A case with 40-year follow-up. Arch Otolaryngol Head Neck Surg 1991;117:439-41.

167. Amble FR, Harner SG, Weiland LH, McDonald TJ, Facer GW. Middle ear adenoma and adenocarcinoma. Otolaryngol Head Neck Surg 1993;109:871-6.

168. Robson AK, Eveson JW, Smith IM, Maw AR. Papillary adenocarcinoma of the middle ear. J Laryngol Otol 1990;104: 915-6.

169. Tory K, Brauch H, Lineham M, et al. Specific genetic change in tumors associated with von Hippel-Landau disease. J Natl Cancer Inst 1989;81:1097-101.

170. Latif F, Tory K, Gnarra J, et al. Identification of the von Hippel-Landau disease tumor suppressor gene. Science 1993;260:1317-20.
171. Gaffey MJ, Mills SE, Boyd JC. Aggressive papillary tumors of middle ear/temporal bone and adnexal papillary cystadenoma. Manifestations of von Hippel-Lindau disease. Am J Surg Pathol 1994;18:1254-60.

172. Megerian LA, Pilch BZ, Bhan AK, McKenna MJ. Differential expression of transthyretin in papillary tumors of the endolymphatic sac and choroid plexus. Laryngoscope 1997; 107:216-21.

173. Medeiros LJ, Michie SA, Johnson DE, Warnke RA, Weiss LM. An immunoperoxidase study of renal cell carcinomas: correlation with nuclear grade, cell type, and histologic pattern. Hum Pathol 1988;19:980-7.

174. Coffin CM, Wick MR, Braun JT, Dehner LP. Choroid plexus neoplasms. Clinicopathologic and immunohistochemical studies. Am J Surg Pathol 1986;10:394-404.

175. Doglioni C, Dell'orto P, Coggi G, Iuzzolina P, Bontempini L, Viale G. Choroid plexus tumors. An immunocytochemical study with particular reference to the coexpression of intermediate filament proteins. Am J Pathol 1987;127:519-29.

176. Ang LC, Taylor AR, Bergin D, Kaufmann JCE. An immunohistochemical study of papillary tumors in the central nervous system. Cancer 1990;65:2712-9.

177. Gottschalk J, Jautzke G, Paulus W, Goebel S, CervosNavarro J. The use of immunomorphology to differentiate choroid plexus tumors from metastatic carcinoma. Cancer 1992;72:1343-9.

178. Gyure KA, Morrison A. Cytokeratin 7 and 20 expression in choroid plexus tumors: utility in differentiating these neoplasms from metastatic carcinomas. Mod Pathol 2000;13: 638-43.

179. Horiguchi H, Sano T, Toi H, Kegji T, Hirokawa M, Nagahiro S. Endolymphatic sac tumor associated with von HippelLindau disease patient: an immunohistochemical study. Mod Pathol 2001;14:727-32. 